\title{
Class and Landscape Level Habitat Fragmentation Analysis in the Bale Mountains National Park, Southeastern Ethiopia
}

Annissa Muhammed ( $\sim$ annissamuhammed@gmail.com )

Arsi University https://orcid.org/0000-0003-3004-4728

Eyasu Elias

Addis Ababa University College of Natural Sciences

\section{Research}

Keywords: Conservation priority, Habitat fragmentation, Landscape structural

Posted Date: December 11th, 2020

DOl: https://doi.org/10.21203/rs.3.rs-125115/v1

License: (c) (1) This work is licensed under a Creative Commons Attribution 4.0 International License.

Read Full License 


\section{Abstract}

\section{Background}

The changes of landscape structure and function due to human interference is hastening worldwide, and it is compulsory to preserve biological resources in a protected system. This study aims to measure the landscape ecological structure and the extent of habitat fragmentation in the Bale mountains national park. The land use/land cover change was determined by interpreting the 1985, 1995, 2005 and 2017 Landsat images with ArcGIS 10.3, and the selected landscape structural metrics was analyzed using FRAGSTATS 4.2.1.

Results

All land cover classes showed a declining trend, except the farmland, and grassland depicted the highest area reduction. From 1985 to 2017 grassland, Erica, forestland, and afro-alpine were decreased by $9.36 \%$, $0.26 \%, 0.06 \%$, and $0.01 \%$, respectively. Whereas, farmland was increased by $43.67 \%$. The study area was characterized as progressively fragmented since it was signified by the escalated value of patch number (40.22\%), area-weighted mean shape index (18.84\%), and edge density $(22.27 \%)$ and a declined value of mean patch size $(28.68 \%)$ and core area $(10.60 \%)$ over the study period. Considering this result, there was a high loss in area available for core dependent species, particularly for Mountain nyala in the grasslands and woodlands, Ethiopian wolf in afro-alpine regions, and Bale monkey in the bamboo forest.

Conclusion

Both forestland and grassland need a conservation priority since these habitats were the most fragmented and habitat lost area.

\section{Introduction}

Most ecosystems worldwide are now heavily transformed particularly the biodiversity hotspots which comprises a high species diversity, harbor endemic species, and lost more than $70 \%$ of their native vegetation (Laurance 2010). Various studies confirmed that anthropogenic habitat loss and fragmentation generally affect ecosystem services which offered by different habitats, including forests, shrubs, and grasslands across landscapes on both spatial and temporal scales (Fetene et al. 2016). This alteration of natural habitats (hereafter habitats) affects ecosystem processes and changes the environment's physical attributes, which ultimately leads to a deteriorated environment (Council 2010). This was due to the human-induced land use and land cover (LULC) changes that rapidly transforms many habitats (Lovejoy and Hannah 2005). The increasing human population, which leads to a growing demand for food and energy, are the primary drivers of land use change and thus habitat loss and fragmentation. The extent of conversion and extra-human alterations of the environment have led to the notion that the earth has entered the era of the Anthropocene (Zalasiewicz et al. 2011). 
The rate of human-induced habitat degradation is increasing worldwide, particularly in regions like Africa, which are experiencing fast population growth (Malcolm et al. 2006). Ecosystems in East Africa are frequently altering owing to complex biophysical and societal factors (Were, Dick, and Singh 2013). The change of land use due to the escalating human population and livestock rearing is a usual experience in protected areas of Ethiopia (Pomeroy et al. 2003). Several studies have been done to assess the degree of LULC change in Ethiopia's highlands and lowlands. Rendering to these reports, the country is marked by a decline of forests, grasslands, and shrublands but a significant expansion of agricultural land and barren lands over time. Inappropriate agricultural practices, increasing human population, and intensive livestock rearing in the Ethiopian highlands caused huge land degradation (Alemu et al. 2015).

Government change, particularly the downfall of the Derg regime in Ethiopia led to the illegal destruction of protected forests and grasslands by farmers and pastoralists in the country.

The Bale Mountains National Park (BMNP) is one of the biological hotspots where such land cover modifications happened steadily over the past two decades (Williams et al. 2004). It was established in 1970 aimed to protect the afro-alpine habitat and its endemic mammals. It represents the largest afroalpine vegetation in Africa and constitutes a large amount of endemic flora and fauna (Yalden and Largen 1992). But it is impacted by excessive settlements, livestock rearing, and human-induced fires even in the afro-alpine region. As a result, large habitats are fragmented and reduce in size as well as small habitats are lost in the park. Therefore, the main objective of this study was to measure the landscape spatial structural change from 1985 to 2017 by considering the Bale mountain national park as a case study site. The specific objectives were (1) to determine the extent of LULC changes between 1985 and 2017; (2) to measure the spatial change on landscape structure; and (3) to explore the causal factors and impacts of landscape structural change in the park. This study suggests to implement important conservation measures in the park such as creating alternative income generation for the park dependent peoples, implementing existing protected area management rules and regulation, preparing future landscape planning, and implementing a restoration intervention strategy.

\section{Materials And Methods}

\section{Description of the study area}

BMNP is located $400 \mathrm{~km}$ southeast of Addis Ababa in Oromia Regional, National State, Ethiopia. It is situated within the geographic bounds of $6^{\circ} 53^{\prime} 08^{\prime \prime} \mathrm{N}$ latitude $39^{\circ} 44^{\prime} 03^{\prime \prime}$ E longitude (Fig. 1). It belongs to the Arsi-Bale-massif, which forms the western segment of the southeastern highlands of Ethiopia. It encompasses a broad range of habitats between 1,500m and 4,377m altitude. Based on the agro-climatic classification of Ethiopia by MoA 2005 and Elias 2016, the study area falls within five agro-ecological zones, that are Semi-Arid (500-1600 m), Sub-Moist (1600-2400 m), Moist (2400-3200 m), Sub-Humid (3200-3800 m), and Humid (above $3800 \mathrm{~m}$ ). Its rainfall distributional pattern is bimodal with heavy rains from July to October, (highest peak in August) and small rains from March to June, (highest peak in April) (Fig. 2). As a result, four major regional rivers (Web, Wabe, Dumel, and Welmel) originate from the park and flow into two major trans-boundary rivers, the Genale and Wabi-Shebelle rivers. The mean monthly 
minimum and maximum temperature are $5.6^{\circ} \mathrm{C}$ and $21.4^{\circ} \mathrm{C}$, respectively (Fig. 2). The park is a globally important center of endemism, harboring $26 \%$ of Ethiopia's endemic species, including Ethiopian wolf, Mountain Nyala, and giant mole-rat (Wakjira, d'Udine, and Crawford 2015). Since the crust of the Bale Mountains is of volcanic origin, it is fairly fertile silty loams of reddish-brown to black clay soils dominated by Vertic Cambisols and Leptosols (Miehe and Miehe 1994).

\section{Data source, image processing and classification}

The sources of data were from satellite-based remote sensors, fieldwork, and ancillary data. Preprocessed Landsat images of the years 1985, 1995, 2005 and 2017 were used to produce time-series datasets of LULC. The Landsat images were purposely selected to correspond with regime change and the country's subsequent policy shift in the 1990s. Three satellite scenes with path/row 167/55, 168/55, and 167/56 were used for each Landsat image. A spatial resolution of $30 \mathrm{~m}$ Landsat-5 TM, Landsat-7 ETM+, and Landsat-8 OLI were acquired from the United States Geological Survey (USGS) Earth Resources Observation web source (http://earthexplorer.usgs.gov/) (Table 1). The Landsat data were extracted and six bands (excluding the thermal band) were stacked using ArcGIS version 10.3 to form multiband images. Image masking, color composite, and sub-setting were done consecutively. The multi-band images were then orthorectified to the geographic projection of the Universal Transverse Mercator (UTM) using the Adindan Ethiopia datum, i.e., World Geodetic System (WGS) 84 datum zone 37N using the nearest neighbor resampling method, geometrically co-registered and subsets prepared.

\section{Table 1 Landsat satellite series used for landscape change}

\begin{tabular}{|llll|}
\hline Satellite and sensor & Path and row & Date of acquisition & Resolution \\
\hline Landsat 5 TM & $167 / 55,168 / 55 \& 167 / 56$ & January 1985 & $30 \mathrm{~m}$ \\
\hline Landsat 7 ETM+ & $167 / 55,168 / 55 \& 167 / 56$ & January 1995 & $30 \mathrm{~m}$ \\
\cline { 2 - 4 } & $167 / 55,168 / 55 \& 167 / 56$ & January 2005 & $30 \mathrm{~m}$ \\
\hline Landsat 8 OLI & $167 / 55,168 / 55 \& 167 / 56$ & January 2017 & $30 \mathrm{~m}$ \\
\hline
\end{tabular}

To classify the images, both unsupervised and supervised image classification techniques were used. Unsupervised classification using the Iterative Self-Organizing (ISO) data algorithm was performed to identify between 20 and 30 spectral clusters in each segment depending on their complexity (Rogan and Chen 2004). Based on ancillary and field data, the resulting clusters were allocated to five land cover groups (grassland, afro-alpine, woodland, Erica, and farmland). Meanwhile, land cover classes have been defined based on the percentage of biophysical cover identified in the field and the modification of definitions by Kidane et al., 2012 and the 2006 USGS National Land Cover Database (Table 2). Supervised image classification with maximum likelihood algorithm (Lillesand, Kiefer, and Chipman 2015) was performed using 300 ground-truthing points (60 points for each LULC classes) obtained from the field using GPS and Google Earth tools (Green 2009). 


\begin{tabular}{|ll|}
\hline $\begin{array}{l}\text { LULC } \\
\text { Classes }\end{array}$ & Description \\
\hline Grassland & $\begin{array}{l}\text { Grassland with }<20 \% \text { bush or shrub cover, grass and herb cover with scattered trees and } \\
\text { shrubs, areas with permanent grass cover. }\end{array}$ \\
\hline $\begin{array}{l}\text { Afro- } \\
\text { alpine }\end{array}$ & $\begin{array}{l}\text { Areas occurred higher than } 3200 \text { meters above sea level and characterized by species } \\
\text { such as Helichrysum and Alchemilla. }\end{array}$ \\
\hline Forestland & $\begin{array}{l}\text { Land covered with dense trees which include evergreen forest, mixed forest, and } \\
\text { plantation forest. }\end{array}$ \\
\hline Erica & $\begin{array}{l}\text { Contain a morphologically diverse range of taxa, including herbs, dwarf shrubs, and } \\
\text { trees commonly found in acid and infertile growing conditions. }\end{array}$ \\
\hline Farmland & \begin{tabular}{l} 
Land plowed/prepared for growing rain-fed or Irrigated crops \\
\hline
\end{tabular}
\end{tabular}

\section{Land use/land cover change detection}

To analyze LULC change, visual comparison of features and matrix analysis (image differentiation) was implemented (Lu et al. 2004). Change statistics were calculated using ArcGIS 10.3 by comparing image values of one set of data with the corresponding value of the second set of data in each period.

Percentage area change across the time of analysis was determined and landscape conversion rate was quantified (Mezgebu and Workineh 2017), as follows:

Percentage change $=\frac{\text { Area of final year-Area of initial year }}{\text { Area of initial year }} \times 100$

Conversion rate $=\frac{\text { Area of final year-Area of initial year }}{\text { Time }}$

Accuracy assessment was carried out to measure the similarity of estimates to the true value (Congalton and Green 2002). Accordingly, 300 validation points (60 points for each LULC classes) were identified and pixels that were categorized under different land-cover polygons were compared using error matrices. Error matrices were represented in terms of producer's accuracy, user's accuracy, overall accuracy (Shao and Wu 2008) and the Kappa coefficient (Mather and Tso 2016). In principle, all the output maps have to meet the minimum $85 \%$ overall accuracy (Anderson 1976) and over $60 \%$ of producer's and user's accuracy (Shao and Wu 2008). All the time Kappa coefficient is less than or equal to 1. A value of 1 implies perfect agreement, between 0.7 and 1 is very good agreement, and $<0.20$ is poor agreement.

The data about the major drivers of LULC change in the study area were collected through field observations and key informant interviews. The questioners were semi-structured and interview with selected people that have knowledge on LULC change and the drivers of the change. The key informants 
were selected based on their responsibility and experience that can provide information about local facts, attitudes, and beliefs. They include elder farmers, natural resource experts, and community leaders.

\section{Quantification of landscape fragmentation}

Nine landscape metrics under two broad categories (landscape composition and configuration metrics) were selected based on a correlation matrix to quantify the spatial characteristics of patches, classes of patches, and the entire landscape mosaic following the procedure by (McGarigal, Cushman, and Ene 2012; Smiraglia et al. 2015). In the first category class area (CA), core area (COA) and patch number (PN) and in the second category edge density (ED), mean patch size (AREA_MN), mean shape index (SHAPE_MN), area-weighted mean shape index (SHAPE_AM), mean Euclidean nearest neighbor distance (ENN_MN) and interspersion and juxtaposition index (IJI) were determined. FRAGSTATS software version 4.2.1 was used to compute the landscape patterns in each land cover class and the entire landscape (McGarigal 2002) and an 8-cell neighborhood rule was followed to define patches (Posada Posada 2012).

\section{Results And Discussion}

\section{Land use/land cover changes}

The LULC change analysis in the BMNP were made from 1985 to 2017 for 32 years and all land cover type depicted an overall decreasing trend in area, except the farmland (Fig. 3; Table 3). Forest lands were dominant for the entire period while farmlands occupied the least area. During the assessment period, two distinct patterns were identified based on the change detection matrix (Fig. 4). These were a decreasing and increasing pattern, particularly, in the grassland and farmland, respectively. This both land cover types shown higher magnitudes of change compared to other land cover types in the entire study periods. Farmland was increased by $26.05 \mathrm{~km}^{2}$ at annual average increasing rates of $1.18 \%$ from its emerging year. This indicates the ongoing transition from natural to the human dominated environment. Increasing human population and expanding land for agriculture is the most important factor influencing land cover in the study area, especially in the grassland. Similar results have been reported in Munessa-Shashemene landscape by (Kindu et al. 2013), in the central highlands of Ethiopia by (Gessesse and Bewket 2014), and in the Muga watershed by (Belay and Mengistu 2019). The overall accuracies of the 1985, 1995, 2005 and 2017 images were $90 \%, 92 \%, 88 \%$, and 93\% with kappa coefficients of $0.86,0.89,0.86$ and 0.91 respectively. This indicates the reliability of the LULC change analysis and the maps produced.

\section{Table 3 Landscape change matrices and area extent from 1985 to 2017}




\begin{tabular}{|llllllllll|}
\hline & $\mathbf{1 9 8 5}$ & & $\mathbf{1 9 9 5}$ & & $\mathbf{2 0 0 5}$ & \multicolumn{2}{c|}{$\mathbf{2 0 1 7}$} & \\
\hline LCCs & $\begin{array}{l}\text { Area } \\
\left(\mathrm{Km}^{2}\right)\end{array}$ & $\mathbf{( \% )}$ & $\begin{array}{l}\text { Area } \\
\left(\mathrm{Km}^{2}\right)\end{array}$ & $\mathbf{( \% )}$ & $\begin{array}{l}\text { Area } \\
\left(\mathrm{Km}^{2}\right)\end{array}$ & $\begin{array}{l}\text { (\%) } \\
\text { Area } \\
\left(\mathrm{Km}^{2}\right)\end{array}$ & $(\%)$ \\
\hline Grassland & 275.25 & 12.64 & 274.85 & 12.62 & 262.62 & 12.06 & 251.70 & 11.56 \\
\hline $\begin{array}{l}\text { Afro- } \\
\text { alpine }\end{array}$ & 293.45 & 13.47 & 293.51 & 13.48 & 293.43 & 13.47 & 293.41 & 13.47 \\
\hline Forestland & 871.95 & 40.04 & 872.25 & 40.05 & 871.74 & 40.03 & 871.44 & 40.02 \\
\hline Erica & 737.12 & 33.85 & 737.16 & 33.85 & 735.32 & 33.76 & 735.18 & 33.76 \\
\hline Farmland & - & - & - & - & 14.67 & 0.67 & 26.05 & 1.20 \\
\hline
\end{tabular}

\section{The extent of habitat fragmentation at the class level}

The analysis of landscape metrics in this study revealed that the BMNP is characterized by an increase in PN and decrease in AREA_MN and this ultimately led to attrition (disappearance of patches), particularly in the grassland, since habitat fragmentation is the precondition for it. From 1985 to 2017 forestland, Erica and grassland shown increasing trend in PN by $93.41 \%, 29.76 \%$, and $6.36 \%$ and a decreasing trend in AREA_MN by $45.81 \%, 22.15 \%$, and $17.93 \%$, respectively. (Oertli et al. 2002 ) stated that high number of separated patches of a habitat indicates high level of fragmentation. Conversely, afro-alpine shows a slight increment in PN by 5.33\% and a modest decrement in AREA_MN by 20.57\% from 1985 to 2017 (Fig. $5 a$ and $b$ ). This could be due to the inaccessibility of this landcover class. Relatively, grassland was the most threatened habitat compared to other land cover classes with $23.55 \mathrm{~km}^{2}$ (about $9.36 \%$ ) total area lose and 3.44 ha (the least) AREA_MN in 2017. This result is in agreement with the result reported by (Fetene et al. 2016) in the Nech Sar national park. Considering PN, forestland constitutes the highest net increment with 2,507 but still it was the highest in AREA_MN with 28.09 ha and this might be due to its larger area coverage (about $40 \%$ of the study area).

The value of SHAPE_AM, which indicates the perimeter-area relationship of patches, was consistently increased for grassland (except in 2017), forestland and farmland throughout the study period (Figure 6a). However, it shows an irregular and opposite pattern for ericaceous and afro-alpine land cover classes. Over the study period, SHAPE_AM increased by $63.40 \%$ for farmland, $47.18 \%$ for forestland, $20.66 \%$ for Erica and $4.15 \%$ for grassland while it decreased by $4.33 \%$ for afro-alpine. Generally, a higher perimeter-area relationship characterizes the rapid rate of fragmentation in the landscape (Flowers, Huang, and Aldana 2020). In contrary, there was inconsistency amongst the value of ED across all land cover classes throughout the study period (Fig. 6b). Throughout the study period, the value of ED increased by $74.54 \%$ for forestland, $30.36 \%$ for farmland, $22.24 \%$ for Erica and $2.78 \%$ for grassland while it decreased by $9.36 \%$ for afro-alpine. As it was emphasized by (McGarigal 2002), the oscillation of ED indicated a major reduction in the spatial heterogeneity of the landscape. This was true in the afro-alpine landcover class. Conversely, the higher value of ED, particularly the forestland in this study, indicates little 
to no central tendency in the ecosystem (Flowers et al. 2020) and resulted invasions and disturbances of the class (Daye and Healey 2015).

All land cover classes shown a declining trend in total COA from 1985 to 2017 and forestland shares the largest COA followed by Erica, afro-alpine, and grassland (Figure 7a). The net COA loss from 1985 to 2017 was higher for grassland with $32.82 \%$ and lowest for forestland with $4.07 \%$. However, compared to the total area, the COA of the afro-alpine reduced at higher rate with $14.15 \%$ and forestland at lower rate with $3.63 \%$. As it was reported in the study by (Kidane, Stahlmann, and Beierkuhnlein 2012), the most dominant practices in the Bale Mountains, especially after 1995, were the upward expansion of agriculture and enrichment plantation. The afro-alpine habitat is distinguished by its vulnerability and high level of endemicity. Such ecosystems, worst of all, have nowhere else to go and are thick at the top of the mountain (Nogués-Bravo et al. 2007). Historically, the afro-alpine habitats were signified as inaccessible and less influenced by human impacts, except the activities of some pastoralists and herders (Kidane et al. 2012). Recent human-induced threats in this region, however, are proliferating.

The mean size of the landscape COA per patch showed a declining trend with net loss of $3.95 \mathrm{~km}^{2}$ (about 19.63\%) from 1985 to 2017 (Fig. 7b). The number of patches containing COA in 2017 was increased by $11.24 \%$ from 1985. The number of patches containing COA in the study area was 7799 in 1985 and 8676 in 2017 (Figure 7c). It was 45\% of the total number of patches in 1985 and $56 \%$ in 2017 . This reflects a growing trend in the number of COA containing patches during the study period and it further confirmed the reduction of mean COA. This result is in agreement with the result reported by (Daye 2012) in southwest Ethiopia. This indicates there is high loss in habitat area available for core dependent species, particularly for mountain Nyala (Tragelaphus buxtoni) in the grasslands and woodlands, Ethiopian wolf (Canis simensis) in afro-alpine regions, and Bale monkey (Cercopithecus djamdjamensis) in bamboo forest of the study area.

ENN_MN was high for the most abundant land cover class in the study area, i.e. forestland, and low for the less abundant land cover class, i.e. afro-alpine. The overall trend depicted that forestland, Erica and farmland shows a declining trend in ENN_MN (Fig. 8a) and this indicates patches become more closer to each other over time. On the other hands, both grassland and afro-alpine habitat showed an increasing trend and patches became isolated from one another over time. At the landscape level, the isolation of patches within the landscape was increased from $105.22 \mathrm{~m}$ to $111.94 \mathrm{~m}$ over time. The large distance between patches of forestland from 1985 to 1995 indicates the low abundance of patches and high AREA_MN of this class. After 1995 a decreasing trend was observed in inter-patch distance for the forestland and that was due to the high rate of change in PN and the rapid adding of new patches. This result is in agreement with the result reported by (Tolessa, Senbeta, and Kidane 2017) in the central highlands of Ethiopia and (Daye 2012) in southwest Ethiopia. Conversely, from 1995 to 2017 the higher inter-patch distance among the grassland patches designates the loss of habitat, since it shows low PN and AREA_MN. This was because the already created patches were rapidly converted into farmlands. The landscape level inter-patch distance of the study area was much lesser compared with the result reported by (Tolessa et al. 2017) in Jibat forest in Ethiopia and (Posada Posada 2012) in the central United States 
eco-regions. This implies that patches of the same class were relatively closer to each other and the extent of habitat loss in the study area was relatively lesser.

Erica depicted the highest IJI value for the whole study period, compared to other land cover classes, but it showed an overall declining trend from 95.38 to 86.77 over the study period (Figure 8b). In contrast forestland was the least in IJI but it showed an increasing trend from 27.02 to 46.94 over time. The landscape-level intermixing of patches in BMNP was ranged from 70.78 to 79.29 . The maximum intermixing of patch by Erica indicates the tendency to have a relatively small AREA_MN and high PN. Instead, the minimum intermixing of patch by forestland designates the tendency to have high AREA_MN and low PN. But the increasing trend of the mean value of $\mathrm{IJI}$ in the forestland shows this land cover class is fragmented more rapidly over the other classes. In the case of farmland, the increasing trend of the $\mathrm{IJ}$ indicates the local communities are introducing new plots of agricultural land in each class. The landscape-level intermixing of patches in the study area was relatively higher compared with the result reported by (Tolessa et al. 2017) in Jibat forest in Ethiopia and (Posada Posada 2012) in the central United States eco-regions. This shows the study area was relatively more fragmented due to the scattered nature of patches.

\section{The extent of habitat fragmentation at the landscape level}

The study area was described by a decline in AREA_MN at the landscape level during both study periods from 8.42 ha in 1985 to 6 ha in 2017. In overall, it was deteriorated by 2.42 ha over the study period. PN markedly increased from 1985 to 2017 by 10,403. Conversely, SHAPE_AM of patches in the landscape showed a declining trend from 1985 to 1995 but it was increased from 1995 to 2017 (Fig. 9). Edge density showed the same pattern with PN. The value of ENN_MN was increased by $1.95 \mathrm{~m}$ but inversely IJI was decreased by 2.23. It is known that with increasing PN, there is an increase in patch density and total edge which is an indicator of landscape fragmentation. As it was stated by (Oertli et al. 2002), high number of separated patches of a habitat indicates high fragmentation. Therefore, the peak of habitat fragmentation for grassland and afro-alpine was in 1995 and for Erica and forestland was in 2017. This result was supported by its low AREA_MN and high ED in same years. This indicates the fragmentation of large and continuous habitats as well as the shrinkage of habitats due to attrition at the edge (Griffiths and Lee 2000).

The occurrence of the main spatial pattern processes of fragmentation, attrition, shrinkage, perforation, and dissection of habitats (Forman 1995) in the study area were proven by evidence of breaking apart of land cover classes, loss of land cover area, decrease in patch size and increase in habitat edge. This is clearly illustrated in Fig. 3 and explained well the processes of expansion and contraction of the land cover classes, as a result of changes in PN, AREA_MN and patch shape. The analysis of this study revealed a growing trend in the level of habitat fragmentation in BMNP. As it was stated by (Oertli et al. 2002), the high number of isolated patches of a habitat indicated the high level of habitat fragmentation. This incident usually occurred due to the increased PN (which leads to an increase in the length of patch 
boundary) and the reduced AREA_MN as a result it halts normal functioning of ecological processes (Collinge 1996).

\section{Causal factors of landscape changes}

The causes of landscape change in the Bale mountains during the last 40 years were rapid population growth, resettlement, agricultural expansion, deforestation, and land clearing, intensified anthropogenic fire (Kidane et al. 2012), and increased frequency of grazing (Amente et al. 2005). From field observation and key informant interview, it was understood that both direct and indirect driving factors have been responsible for the changes in the landscape of the BMNP. Among the direct driving factor farmland expansion, illegal logging, overgrazing, and expansion of rural settlements were the main proximate drivers in the park. This result coincides with previous studies in Ethiopia by (Belay and Mengistu 2019; Demissie et al. 2017; Kindu et al. 2015; Yalew et al. 2016). Forest fire was the main reason of landscape change owing to illegal hunting, honey harvesting, and farmland clearing. The afro-alpine scrublands were also burnt by farmers to initiate fresh grass for their cattle. Hence, the grassland region has deteriorated over time due to the impact of overgrazing, cropland expansion, and settlement in the park. This is coherent with previous studies made by (Gessesse and Bewket 2014; Wubie, Assen, and Nicolau 2016). The indirect driving factors mentioned in the focus group discussion include rapid population growth and climate related shocks. Rapid population growth increases the demands for farmland, grazing land and firewood (Malthus 1966) and ultimately leads to habitat fragmentation and decreased productivity. The climate related shocks identified in the study area are coinciding with the result in (Gessesse and Bewket 2014) study in the central highlands of Ethiopia. It was clear from field observation and key informant interview that in previous year's barley was cultivated below $2400 \mathrm{~m}$ asl. However, it is now cultivated on the steeper, well-drained lower areas of the afro-alpine zone up to 3,700 $\mathrm{m}$ asl. This is essentially due to the change of local climatic conditions, mainly the warmer states of the upper escarpment of the park. Of all drivers, habitat loss and fragmentation due to LULC change in synergy with climate change will remain a paramount issue of biodiversity conservation (Olson et al. 2012) in the study area.

\section{Ecological consequences of landscape change}

Landscape change alters many ecological functions including changes in species composition, trophic structure, and biogeochemical cycle (Laurance and Vasconcelos 2009). The landscape change in the BMNP negatively affected plant and wildlife communities in various level. With the intrusion of grazing and agriculture to forest and alpine ecosystems, anthropogenic land use types have cut ecosystem connectivity where it affects the ecological functioning (Mezgebu and Workineh 2017). Habitat fragmentation, in the plant communities, most importantly affected the propagation of successional plant species than primary vegetation types (Chazdon 2008). For certain plants, pollination success may decline due to specialized pollinators disappearance from fragments (Laurance and Vasconcelos 2009) as a result the plant species richness deprived. From the regression analysis made in this study PN established strong and negative effect on species richness (with $r=-0.90, p<0.05$ ) and diversity (with $r=$ 
$-0.96, p<0.05)$. When the number of fragmented habitats increases species richness and diversity, particularly interior dependent species, declines. However, edge dependent species comfortably flourish. PN and AREA_MN were strong and negatively correlated $(r=-0.71, p<0.001)$. This implies that as the PN increases the area of fragments decreases as a result small fragments contain smaller species richness and lowers species density than large fragments (Laurance and Vasconcelos 2009). Besides, one of the consequences of habitat fragmentation is an increase in the proportional abundance of edge influenced habitat and its adverse impacts on interior sensitive species (Robbins, Dawson, and Dowell 1989). Many population and community changes in habitat fragments were commonly attributed to edge effects (Laurance and Vasconcelos 2009). The most threatened endemic woody species due to edge effect in the BMNP was Helichrysum harennense Mesfin, Kniphofia insignis Rendle, Rubus erlangeri Engl., and Vepris dainellii Pichi. Serm. Kokwaro. Conversely, the most common weed species in the study area favored by edge effect was Achyranthes aspera L., which is also common in the disturbed forests and forest edges of the dry Afromontane forests and moist Afromontane forests in Ethiopia (Friis, Demissew, and Van Breugel 2010).

Moreover, habitat fragmentation in mountain ecosystems has also been a recurring problem for wild mammals in the central highlands of Ethiopia (Kasso and Bekele 2014). The impact, especially posed a persistent challenge to the viability and conservation activities of endemic animals (Mekonnen et al. 2017). This is because animals are migrating from patches to patches, in a fragmented ecosystem, in search of food and water. These trend in the BMNP imposed a direct threat to the movement of the country's most charismatic endemic and endangered mammalians of mountain nyala (Tragelaphus buxtoni) and the Ethiopian wolf (Canis simensis). Eventually, it was responsible for their excessive population reduction for the past three decades (Mamo, Pinard, and Bekele 2010).

\section{Implication for habitat conservation and restoration}

Over the last 32 years the rate of landscape modification in the BMNP has been augmented, especially, in the grassland and afro-alpine land. Although, forestland was the highest fragmented land cover, due to its highest rate of PN increment and AREA_MN decrement, and in the future, this threat will possibly grow into habitat loss since habitat fragmentation is the pre-condition for it. As it was stated by (Fischer and B. Lindenmayer 2006), habitat fragmentation always goes together with habitat loss and decrease in metapopulations. AREA_MN has been a decreased due to the high rate of habitat fragmentation and PN increment. This indicates a shift in the landscape matrix with decreasing connectivity and more fragmented habitats as farmland expands. Despite the decrease in AREA_MN, habitat COA was also reduced. This indicates the core dependent species are under pressure and more likely to be extinct unless some conservation measures are undertaken. The fragmented forest patches in the park are natural ecosystems that provide local communities with timber, food, fuel, wild fruit, spices, and medicinal plants. Their role as a location of organic coffee production, particularly those patches in Magnetea and Harenna Buluk areas, is critical and important for the national economy. More fundamentally, the ecosystems in the park are important in delivering the ecosystem services of regulating climate, purification of air and water, maintaining soil fertility by controlling erosion, and 
pollination of crops (MEA 2005). Therefore, ecosystem conservation and landscape restoration activities have to be made by the park administrators, local communities, and NGOs. Two ecological approaches must be implemented by the park administrators to avoid the potential human impacts on the natural resources and rehabilitate the degraded ecosystems in the park. First, settlers in the park should be relocated to other places outside the park by providing enough and productive land to each household for their farming activities. Second, the relocated communities should be formally organized and involved in ecotourism businesses to generate additional income and to develop a sense of ownership. More importantly, the indigenous knowledge and wisdom on the conservation of nature (Kelbessa 2005) have to be extracted from elders and use it to reverse the degrading state of the ecosystems in the park.

\section{Conclusion}

The LULC changes and landscape structural analysis were integrated to measure the extent of fragmentation in the study area. Evidence from this study revealed the change in the spatial landscape structure and transformations of land cover over the past three decades from 1985 to 2017 . The landscape of BMNP was characterized as moderately fragmented as it was signified by a grown value of PN, SHAPE_AM and ED and a declined value of AREA_MN. In this study it was observed that both the class and landscape level fragmentation was increased over time and the urgent ecological restoration and conservation effort should be implemented to minimize its potential impact on the wildlife population and vegetation cover. This was due to the adverse impact of human settlement and the resulted LULC changes. The increasing levels of resource exploitation in BMNP are projected to threaten many of the ecosystem services to the surrounding valleys and lowlands. Therefore, comprehensive and sustainable environmental approaches should be developed and executed that combine the restoration and protection of the natural ecosystems with the improvement of agricultural productivity. Moreover, patch level habitat conservation strategies must be practiced to improve the interconnectivity of isolated patches in the landscape. Human inducing factors in the park should be banned and settlements in the park should be relocated into other productive areas to practice their agricultural activities to sustain their life meanwhile to let to recover the degraded habitats in the park. Moreover, indigenous knowledge and traditional beliefs must be recognized to conserve natural resources in the study area. Alternatively, policies that focus on sustainable natural resource management have to be articulated and enforced to achieve ecological and socio-economic well-being in the study area. The patches surrounded by an agricultural matrix should also receive conservation attention. The outputs of this study would provide a good base for policy makers with geospatial knowledge. Future research needs to assess the impact of land cover changes on ecosystem services and to project the patterns of future land cover changes.

\section{Abbreviations}

AREA_MN: Mean patch size; BMNP: Bale Mountains National Park; COA: Core area; ED: Edge density, ENN_MN: Mean Euclidean nearest neighbor distance; IJI: Interspersion and juxtaposition index; LULC: 
Land use and land cover; PN: Patch number; SHAPE_MN: Mean shape index; UTM: Universal Transverse Mercator; WGS: World Geodetic System.

\section{Declarations}

\section{Authors' contributions}

AM conceived, designed, collected the data, analyzed and wrote the manuscript. EE supervised the inception, design and edited the manuscript. All authors read and approved the final manuscript.

\section{Acknowledgements}

The authors would like to thank the Ethiopian ministry of science and higher education for funding this research and the Ethiopian wildlife authority for giving permission to conduct this study on site.

\section{Competing interests}

The authors declare that they have no competing interests.

\section{Availability of data and materials}

The data used in this paper can be provided upon request.

\section{Consent for publication}

Not applicable.

\section{Ethics approval and consent to participate}

Not applicable.

\section{Funding}

This research was funded by Ethiopian ministry of science and higher education.

\section{References}

Alemu, Binyam, Efrem Garedew, Zewdu Eshetu, and Habtemariam Kassa. 2015. "Land Use and Land Cover Changes and Associated Driving Forces in North Western Lowlands of Ethiopia." International Research Journal of Agricultural Science and Soil Science 5(1):28-44.

Amente, Stefano, Giuliana Napolitano, Paolo Licciardo, Maria Monti, Piero Pucci, Luigi Lania, and Barbara Majello. 2005. "Identification of Proteins Interacting with the RNAPII FCP1 Phosphatase: FCP1 Forms a Complex with Arginine Methyltransferase PRMT5 and It Is a Substrate for PRMT5-mediated Methylation." FEBS Letters 579(3):683-89. 
Anderson, James Richard. 1976. A Land Use and Land Cover Classification System for Use with Remote Sensor Data. Vol. 964. US Government Printing Office.

Belay, Tatek and Daniel Ayalew Mengistu. 2019. "Land Use and Land Cover Dynamics and Drivers in the Muga Watershed, Upper Blue Nile Basin, Ethiopia." Remote Sensing Applications: Society and Environment 15:100249.

Chazdon, Robin L. 2008. “Beyond Deforestation: Restoring Forests and Ecosystem Services on Degraded Lands." Science 320(5882):1458-60.

Collinge, Sharon K. 1996. “Ecological Consequences of Habitat Fragmentation: Implications for Landscape Architecture and Planning." Landscape and Urban Planning 36(1):59-77.

Congalton, Russell G. and Kass Green. 2002. Assessing the Accuracy of Remotely Sensed Data: Principles and Practices. CRC press.

Council, Victorian Environmental Assessment. 2010. Remnant Native Vegetation Investigation Discussion Paper: For Public Comment: June 2010. Victorian Environmental Assessment Council.

Daye, Desalegn Desissa. 2012. "Fragmented Forests in South-West Ethiopia: Impacts of Land-Use Change on Plant Species Composition and Priorities for Future Conservation." Prifysgol Bangor University.

Daye, Desalegn Desissa and John R. Healey. 2015. "Impacts of Land-Use Change on Sacred Forests at the Landscape Scale." Global Ecology and Conservation 3:349-58.

Demissie, Fikirte, Kumelachew Yeshitila, Mengistie Kindu, and Thomas Schneider. 2017. "Land Use/Land Cover Changes and Their Causes in Libokemkem District of South Gonder, Ethiopia." Remote Sensing Applications: Society and Environment 8:224-30.

Fetene, Aramde, Thomas Hilker, Kumelachew Yeshitela, Ruediger Prasse, Warren Cohen, and Zhiqiang Yang. 2016. "Detecting Trends in Landuse and Landcover Change of Nech Sar National Park, Ethiopia." Environmental Management 57(1):137-47.

Fischer, Joern and David B. Lindenmayer. 2006. "Beyond Fragmentation: The Continuum Model for Fauna Research and Conservation in Human-modified Landscapes." Oikos 112(2):473-80.

Flowers, Bryon, Kuo-Tsang Huang, and Gerardo O. Aldana. 2020. "Analysis of the Habitat Fragmentation of Ecosystems in Belize Using Landscape Metrics." Sustainability 12(7):3024.

Forman, Richard T. T. 1995. "Some General Principles of Landscape and Regional Ecology." Landscape Ecology 10(3):133-42. 
Friis, Ib, Sebsebe Demissew, and Paulo Van Breugel. 2010. Atlas of the Potential Vegetation of Ethiopia. Det Kongelige Danske Videnskabernes Selskab.

Gessesse, Berhan and Woldeamlak Bewket. 2014. "Drivers and Implications of Land Use and Land Cover Change in the Central Highlands of Ethiopia: Evidence from Remote Sensing and Socio-Demographic Data Integration." Ethiopian Journal of the Social Sciences and Humanities 10(2):1-23.

Green, Kass. 2009. Assessing the Accuracy of Remotely Sensed Data: Principles and Practices. CRC Press.

Griffiths, G. H. and J. Lee. 2000. "Landscape Pattern and Species Richness; Regional Scale Analysis from Remote Sensing." International Journal of Remote Sensing 21(13-14):2685-2704.

Kasso, Mohammed and Afework Bekele. 2014. "Threats to Mammals on Fragmented Habitats around Asella Town, Central Ethiopia." International Journal of Biodiversity 2014.

Kelbessa, Workineh. 2005. "The Rehabilitation of Indigenous Environmental Ethics in Africa." Diogenes 52(3):17-34.

Kidane, Yohannes, Reinhold Stahlmann, and Carl Beierkuhnlein. 2012. "Vegetation Dynamics, and Land Use and Land Cover Change in the Bale Mountains, Ethiopia." Environmental Monitoring and Assessment 184(12):7473-89.

Kindu, Mengistie, Thomas Schneider, Demel Teketay, and Thomas Knoke. 2013. "Land Use/Land Cover Change Analysis Using Object-Based Classification Approach in Munessa-Shashemene Landscape of the Ethiopian Highlands." Remote Sensing 5(5):2411-35.

Kindu, Mengistie, Thomas Schneider, Demel Teketay, and Thomas Knoke. 2015. “Drivers of Land Use/Land Cover Changes in Munessa-Shashemene Landscape of the South-Central Highlands of Ethiopia." Environmental Monitoring and Assessment 187(7):452.

Laurance, William F. 2010. "Habitat Destruction: Death by a Thousand Cuts." Conservation Biology for All 1(9):73-88.

Laurance, William F. and Heraldo L. Vasconcelos. 2009. "Deforestation and Forest Fragmentation in the Amazon." Tropical Biology and Conservation Management 2:23-29.

Lillesand, Thomas, Ralph W. Kiefer, and Jonathan Chipman. 2015. Remote Sensing and Image Interpretation. John Wiley \& Sons.

Lovejoy, Thomas E. and Lee Hannah. 2005. "Global Greenhouse Gas Levels and the Future of Biodiversity." 387-95. 
Lu, Dengsheng, P. Mausel, E. Brondizio, and Emilio Moran. 2004. "Change Detection Techniques." International Journal of Remote Sensing 25(12):2365-2401.

Malcolm, Jay R., Canran Liu, Ronald P. Neilson, Lara Hansen, and L. E. E. Hannah. 2006. "Global Warming and Extinctions of Endemic Species from Biodiversity Hotspots." Conservation Biology 20(2):538-48.

Malthus, Thomas Robert. 1966. "First Essay on Population. New York: St."

Mamo, Yosef, Michelle A. Pinard, and Afework Bekele. 2010. "Demography and Dynamics of Mountain Nyala Tragelaphus Buxtoni in the Bale Mountains National Park, Ethiopia." Current Zoology 56(6).

Mather, Paul and Brandt Tso. 2016. Classification Methods for Remotely Sensed Data. CRC press.

McGarigal, K. 2002. "FRAGSTATS: Spatial Pattern Analysis Program for Categorical Maps. Computer Software Program Produced by the Authors at the University of Massachusetts, Amherst." Http://Www. Umass. Edu/Landeco/Research/Fragstats/Fragstats. Html.

McGarigal, Kevin, Sam A. Cushman, and Eduard Ene. 2012. "FRAGSTATS v4: Spatial Pattern Analysis Program for Categorical and Continuous Maps." Computer Software Program Produced by the Authors at the University of Massachusetts, Amherst. Available at the Following Web Site: Http://Www. Umass. Edu/Landeco/Research/Fragstats/Fragstats. Html.

MEA, Millennium Ecosystem Assessment. 2005. "Ecosystems and Human Well-Being: Current State and Trends." Millennium Ecosystem Assessment, Global Assessment Reports.

Mekonnen, Addisu, Peter J. Fashing, Afework Bekele, R. Adriana Hernandez-Aguilar, Eli K. Rueness, Nga Nguyen, and Nils Chr Stenseth. 2017. "Impacts of Habitat Loss and Fragmentation on the Activity Budget, Ranging Ecology and Habitat Use of Bale Monkeys (Chlorocebus Djamdjamensis) in the Southern Ethiopian Highlands." American Journal of Primatology 79(7):e22644.

Mezgebu, Adane and Getachew Workineh. 2017. "Changes and Drivers of Afro-Alpine Forest Ecosystem: Future Trajectories and Management Strategies in Bale Eco-Region, Ethiopia." Ecological Processes 6(1):42.

Miehe, Sabine and Georg Miehe. 1994. Ericaceous Forests and Heathlands in the Bale Mountains of South Ethiopia. Ecology and Man's Impact. Warnke.

Nogués-Bravo, David, Miguel B. Araújo, M. P. Errea, and J. P. Martinez-Rica. 2007. “Exposure of Global Mountain Systems to Climate Warming during the 21st Century." Global Environmental Change 17(34):420-28.

Oertli, Beat, Dominique Auderset Joye, Emmanuel Castella, Raphaelle Juge, Diana Cambin, and JeanBernard Lachavanne. 2002. "Does Size Matter? The Relationship between Pond Area and Biodiversity." Biological Conservation 104(1):59-70. 
Olson, David, Dominick A. DellaSala, Reed F. Noss, James R. Strittholt, Jamie Kass, Marni E. Koopman, and Thomas F. Allnutt. 2012. "Climate Change Refugia for Biodiversity in the Klamath-Siskiyou Ecoregion." Natural Areas Journal 32(1):65-75.

Pomeroy, D. E., Joy Tukahirwa, Samuel Mugisha, Robinah Nanyunja, Mary Namaganda, and Nathan Chelimo. 2003. Linkages between Changes in Land Use, Land Degradation and Biodiversity in SW Uganda. LUCID Project, International Livestock Research Institute.

Posada Posada, Martha Isabel. 2012. “Using Landscape Pattern Metrics to Characterize Ecoregions.” Robbins, Chandler S., Deanna K. Dawson, and Barbara A. Dowell. 1989. "Habitat Area Requirements of Breeding Forest Birds of the Middle Atlantic States." Wildlife Monographs 3-34.

Rogan, J. and D. Chen. 2004. "Remote Sensing Technology for Land Cover and Land Use Mapping and Monitoring." Progress in Planning 61(4):301-25.

Shao, Guofan and Jianguo Wu. 2008. "On the Accuracy of Landscape Pattern Analysis Using Remote Sensing Data." Landscape Ecology 23(5):505-11.

Smiraglia, D., T. Ceccarelli, S. Bajocco, L. Perini, and L. Salvati. 2015. “Unraveling Landscape Complexity: Land Use/Land Cover Changes and Landscape Pattern Dynamics (1954-2008) in Contrasting Peri-Urban and Agro-Forest Regions of Northern Italy." Environmental Management 56(4):916-32.

Tolessa, Terefe, Feyera Senbeta, and Moges Kidane. 2017. "The Impact of Land Use/Land Cover Change on Ecosystem Services in the Central Highlands of Ethiopia." Ecosystem Services 23:47-54.

Wakjira, Dereje Tadesse, Floris d'Udine, and Alec Crawford. 2015. “Migration and Conservation in the Bale Mountains Ecosystem." IISD Report.

Were, K. O., Ø. B. Dick, and B. R. Singh. 2013. "Remotely Sensing the Spatial and Temporal Land Cover Changes in Eastern Mau Forest Reserve and Lake Nakuru Drainage Basin, Kenya." Applied Geography 41:75-86.

Williams, S., J. L. Vivero Pol, S. Spawls, A. Shimelis, and E. Kelbessa. 2004. "Ethiopian Highlands.” Hotspots Revisited: Earths Biologically Richest and Most Endangered Ecoregions. -Mexico City (CEMEX).

Wubie, Mesfin Anteneh, Mohammed Assen, and Melanie D. Nicolau. 2016. “Patterns, Causes and Consequences of Land Use/Cover Dynamics in the Gumara Watershed of Lake Tana Basin, Northwestern Ethiopia." Environmental Systems Research 5(1):8.

Yalden, D. W. and M. J. Largen. 1992. "The Endemic Mammals of Ethiopia." Mammal Review 22(34):115-50. 
Yalew, Seleshi G., Ann van Griensven, Marlous L. Mul, and Pieter van der Zaag. 2016. "Land Suitability Analysis for Agriculture in the Abbay Basin Using Remote Sensing, GIS and AHP Techniques." Modeling Earth Systems and Environment 2(2):101.

Zalasiewicz, Jan, Mark Williams, Alan Haywood, and Michael Ellis. 2011. "The Anthropocene: A New Epoch of Geological Time?"

\section{Figures}

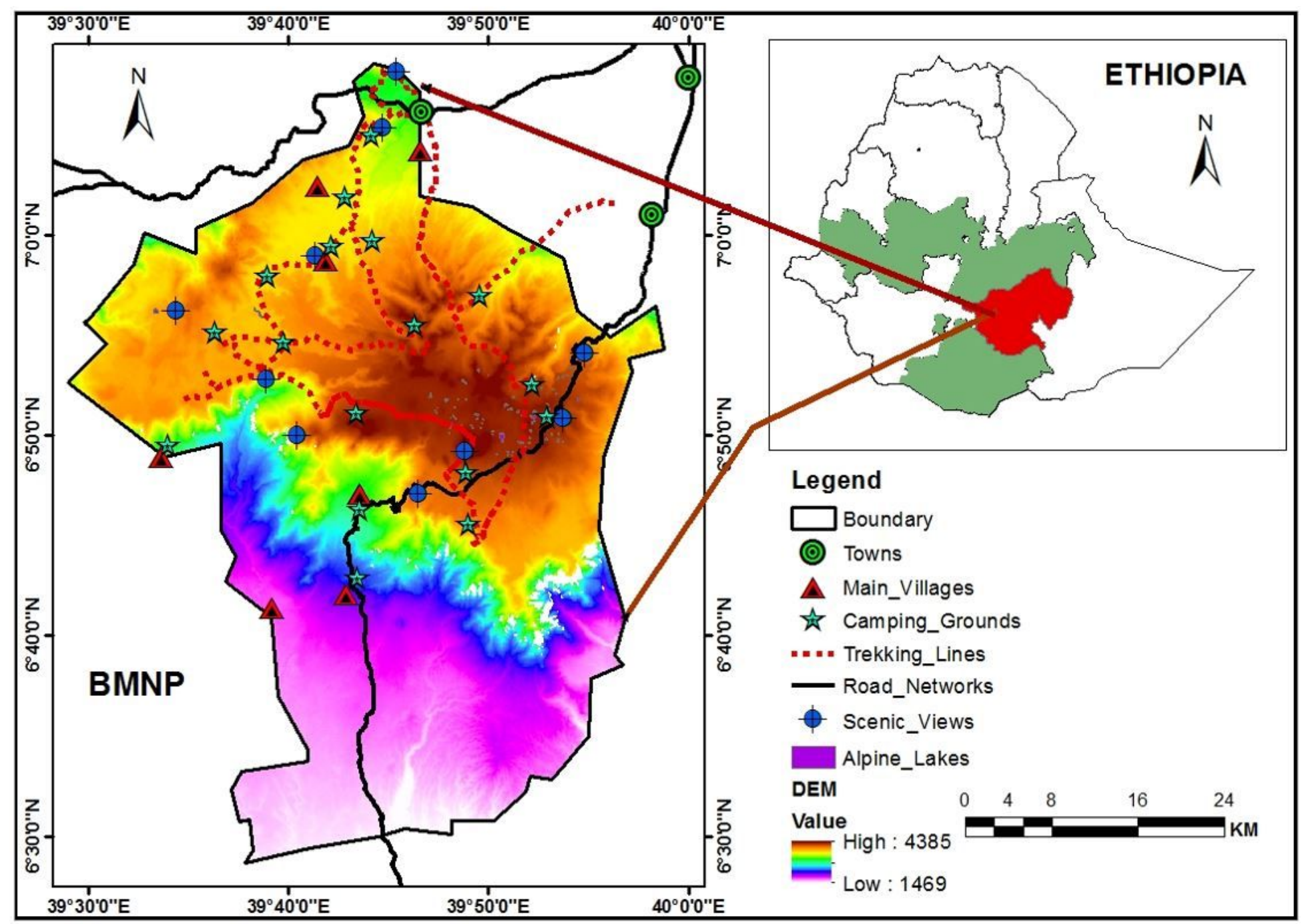

Figure 1

Map of the study area Note: The designations employed and the presentation of the material on this map do not imply the expression of any opinion whatsoever on the part of Research Square concerning the legal status of any country, territory, city or area or of its authorities, or concerning the delimitation of its frontiers or boundaries. This map has been provided by the authors. 


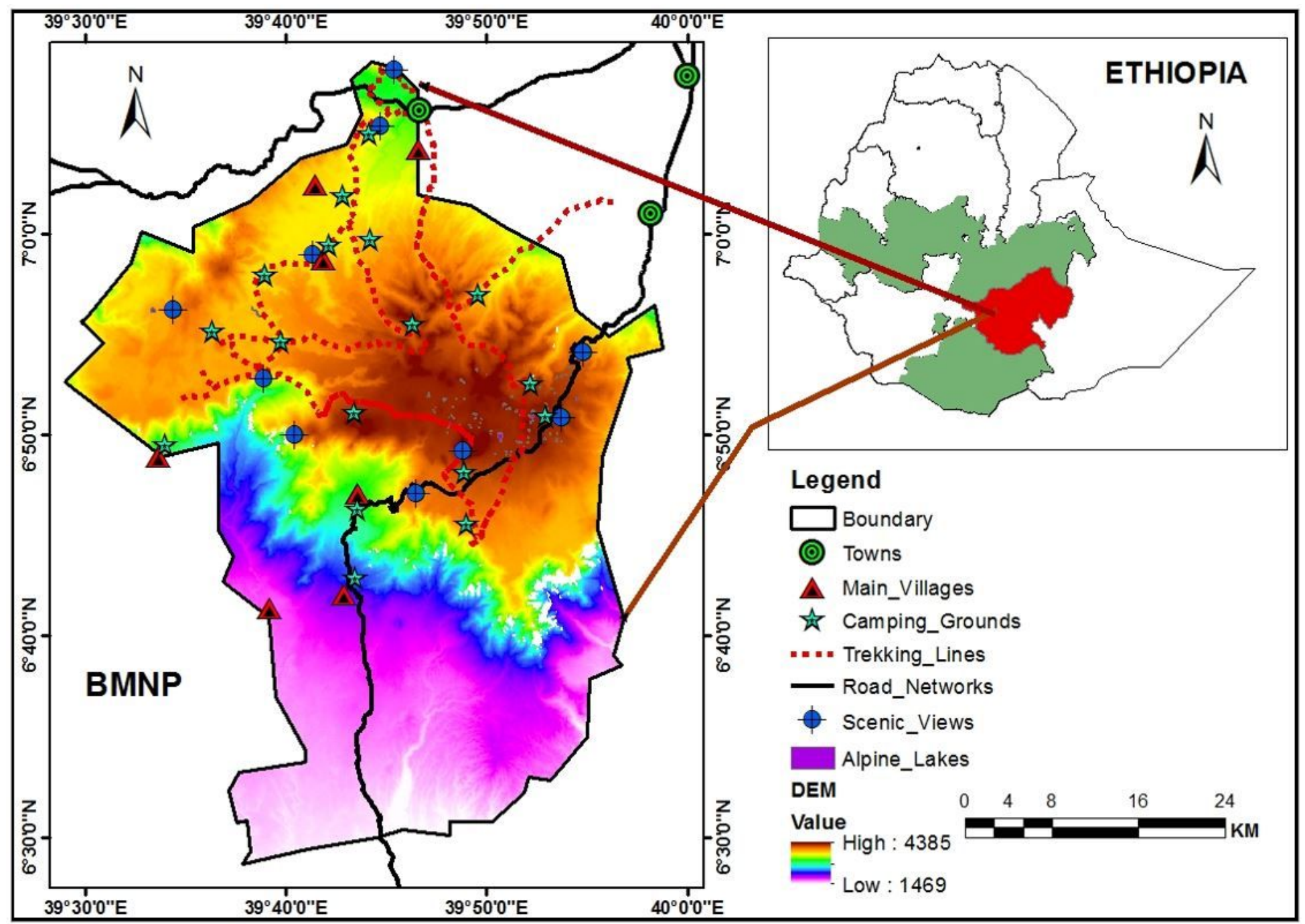

Figure 1

Map of the study area Note: The designations employed and the presentation of the material on this map do not imply the expression of any opinion whatsoever on the part of Research Square concerning the legal status of any country, territory, city or area or of its authorities, or concerning the delimitation of its frontiers or boundaries. This map has been provided by the authors. 


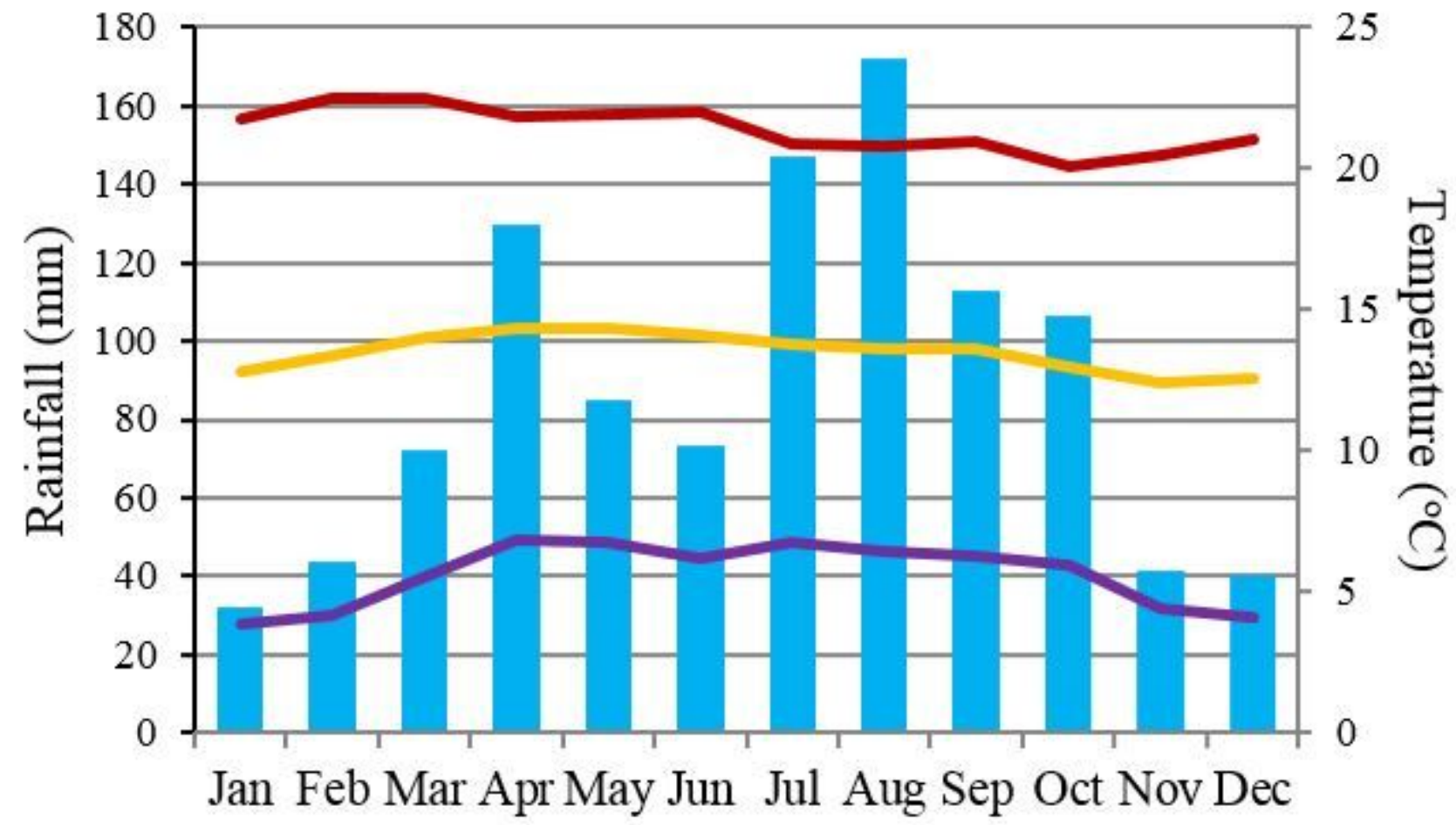

Mean monthly Rainfall (mm)

Min monthly temperature (oC)
Max monthly temperature (oC) Mean monthly temperature (oC)

Figure 2

Mean monthly rainfall and temperature (Source: NMA) 


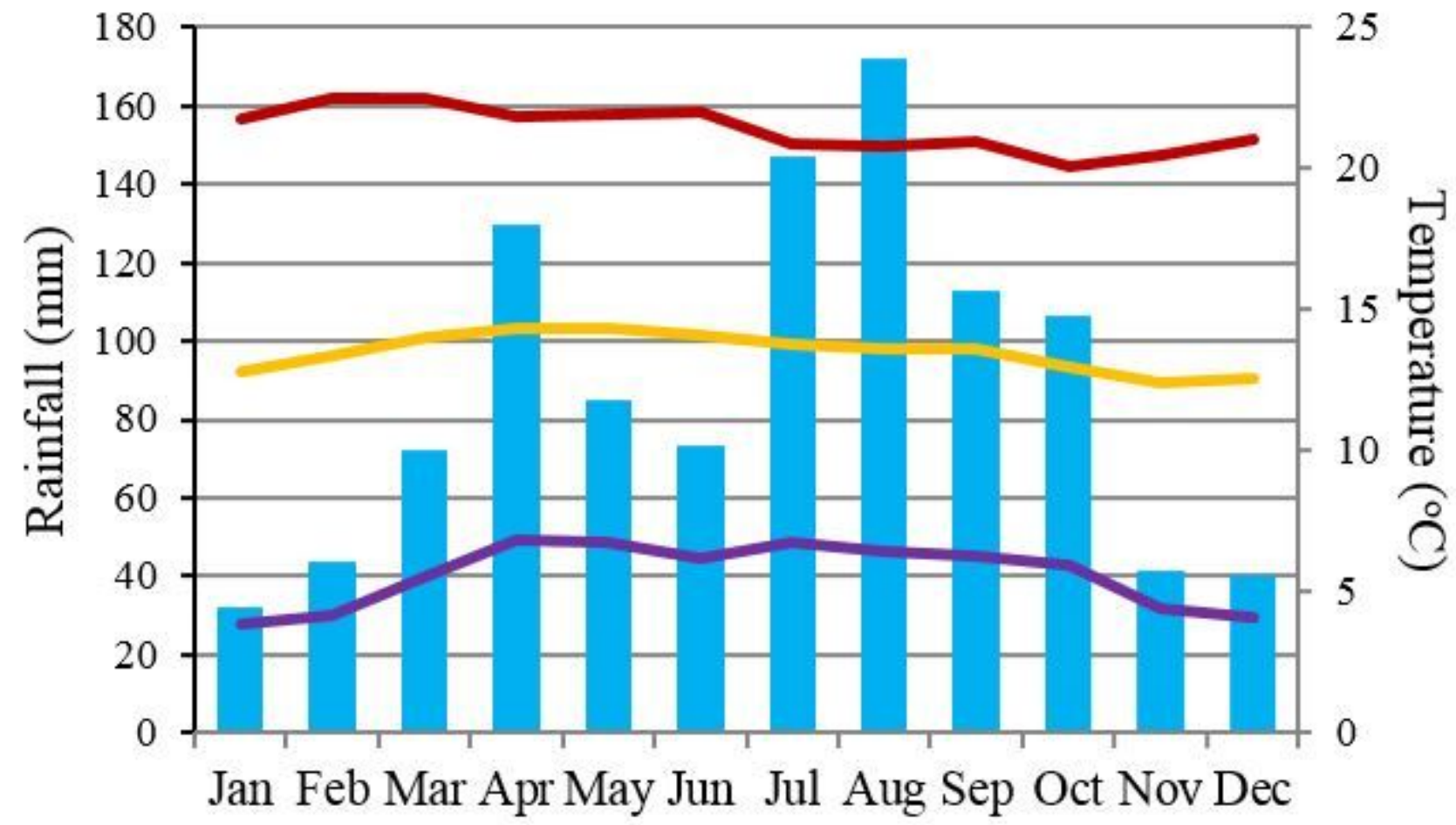

Mean monthly Rainfall (mm)

Min monthly temperature (oC)
Max monthly temperature (oC) Mean monthly temperature (oC)

Figure 2

Mean monthly rainfall and temperature (Source: NMA) 


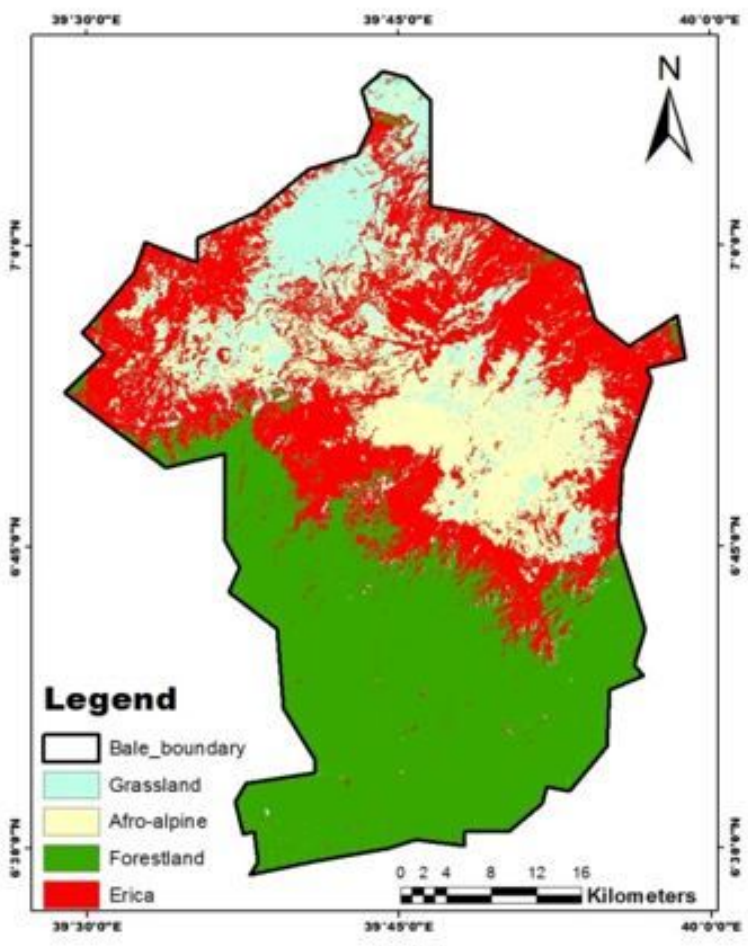

(a)

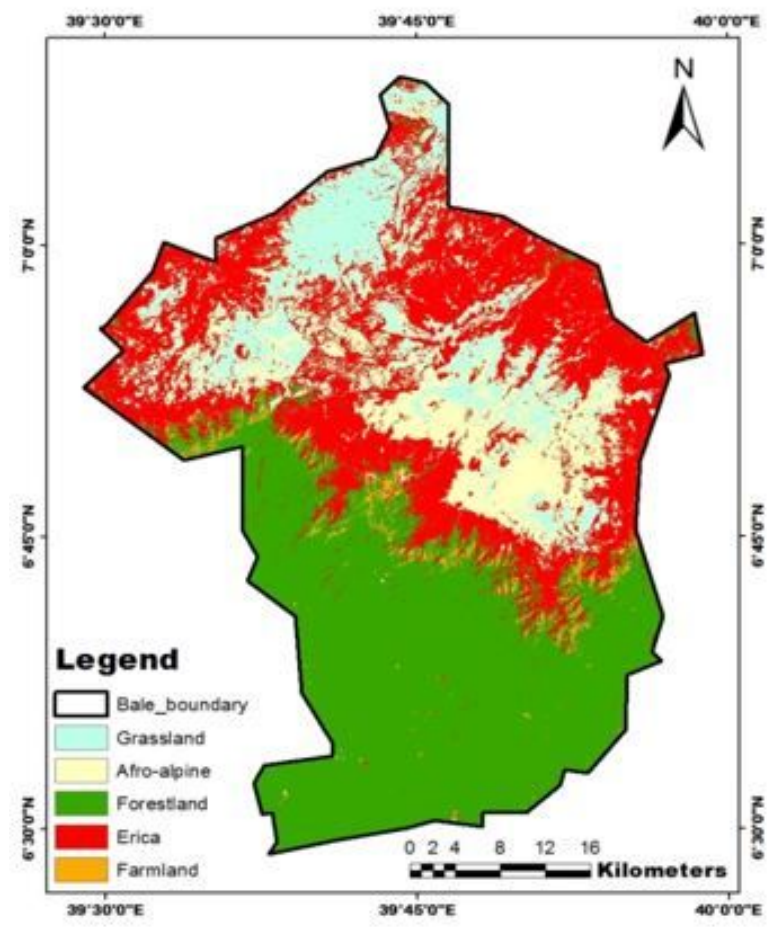

(c)

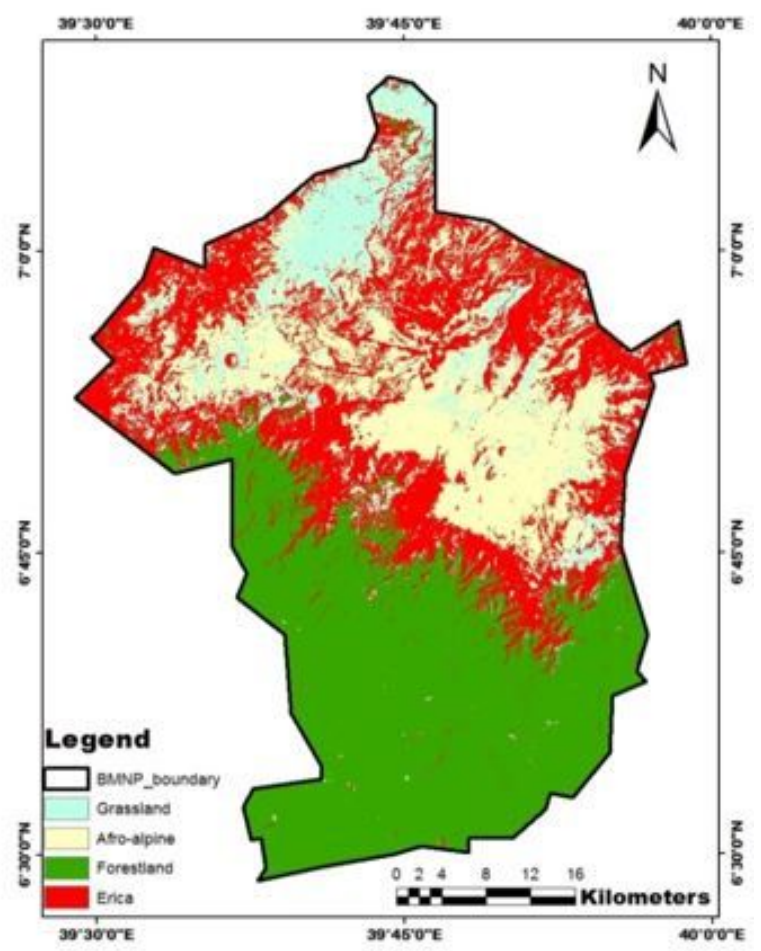

(b)

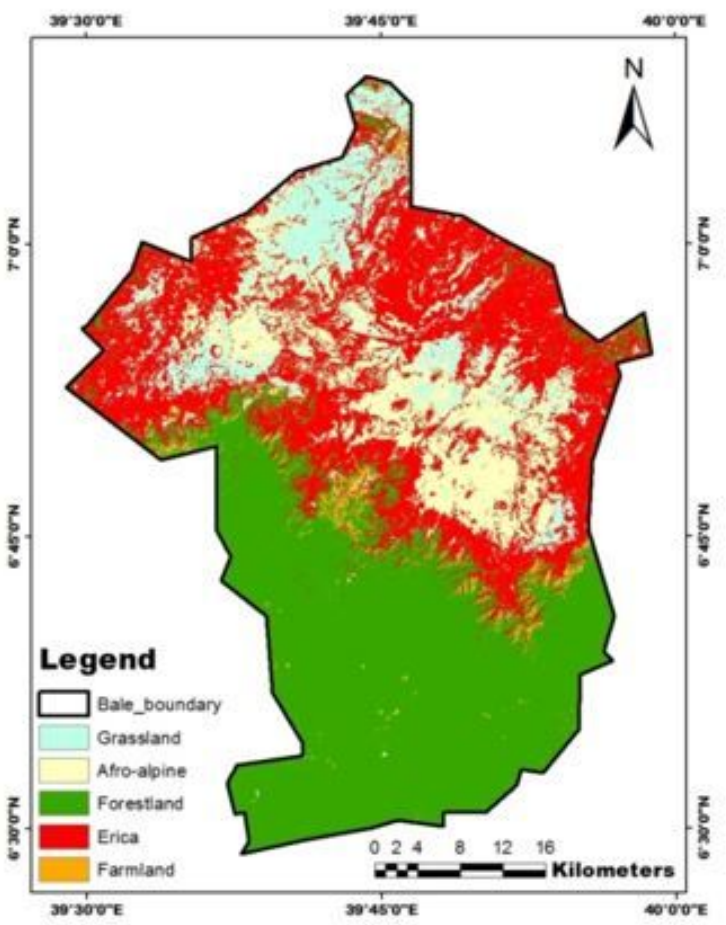

(d)

Figure 3

LULC map of the BMNP for the year 1985 (a), 1995 (b), 2005 (c) and 2017 (d) 


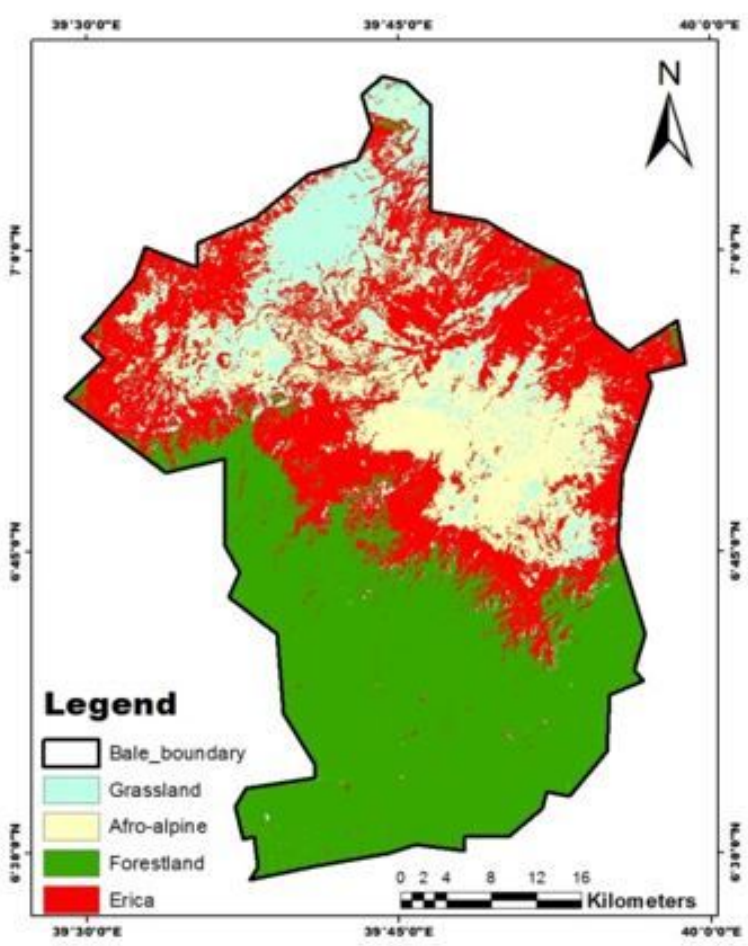

(a)

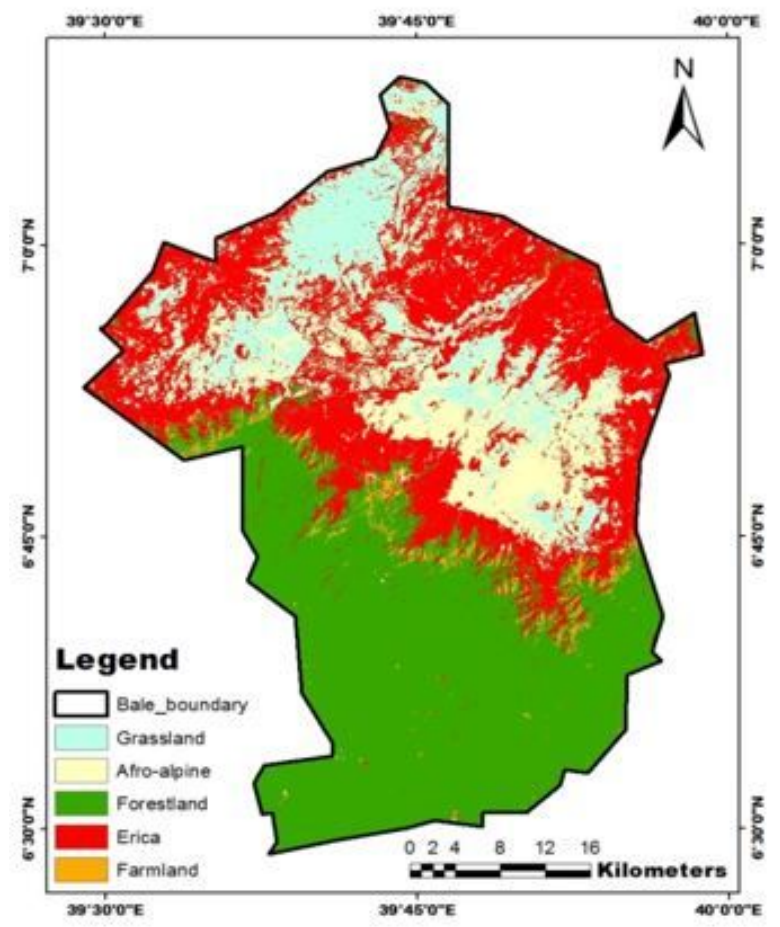

(c)

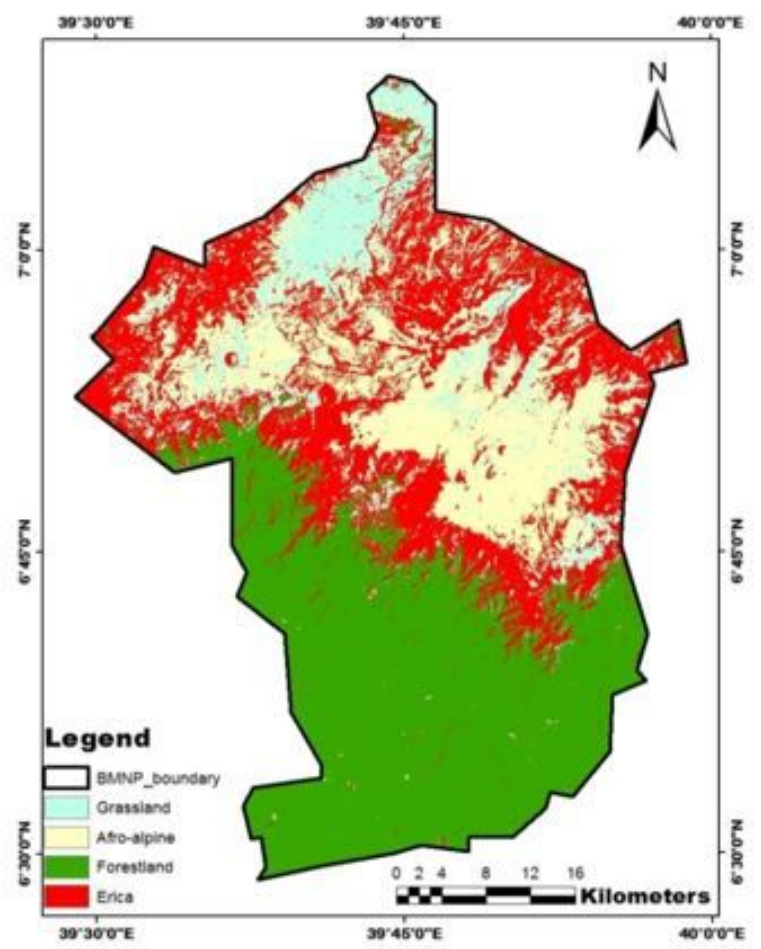

(b)

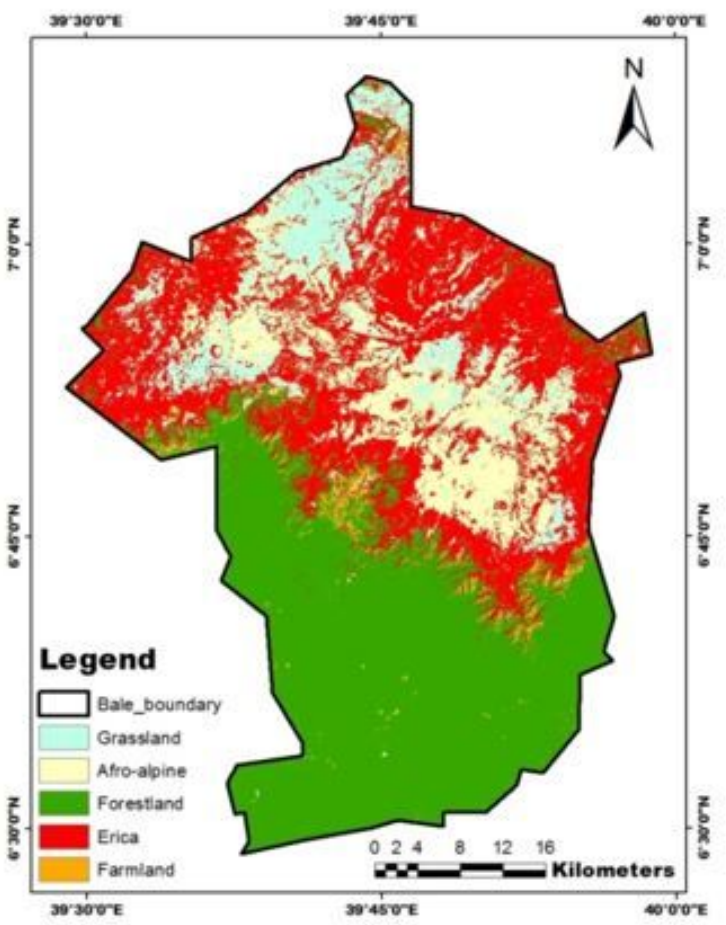

(d)

Figure 3

LULC map of the BMNP for the year 1985 (a), 1995 (b), 2005 (c) and 2017 (d) 


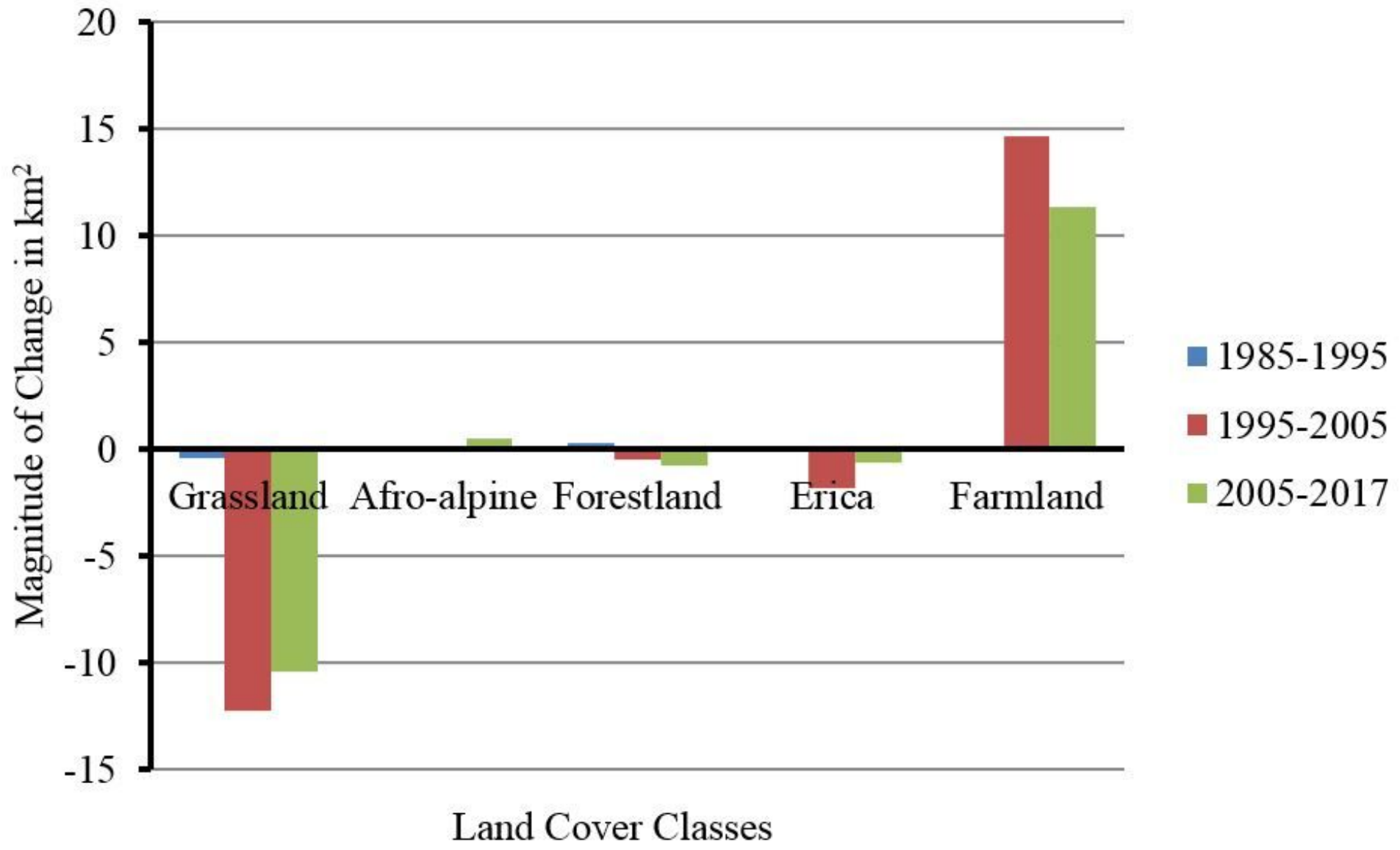

Figure 4

Comparative illustrations of the magnitude of land cover change 


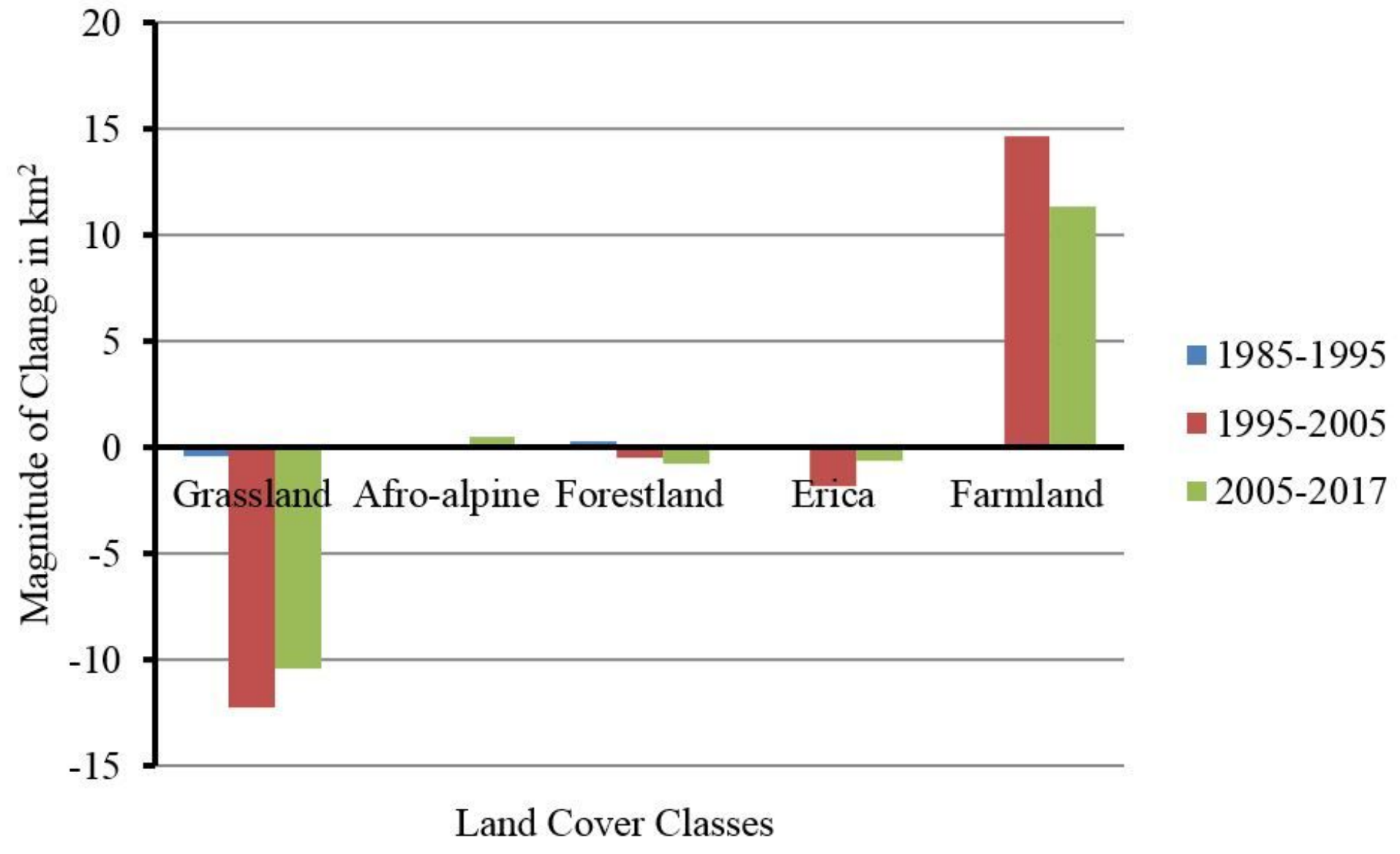

Figure 4

Comparative illustrations of the magnitude of land cover change

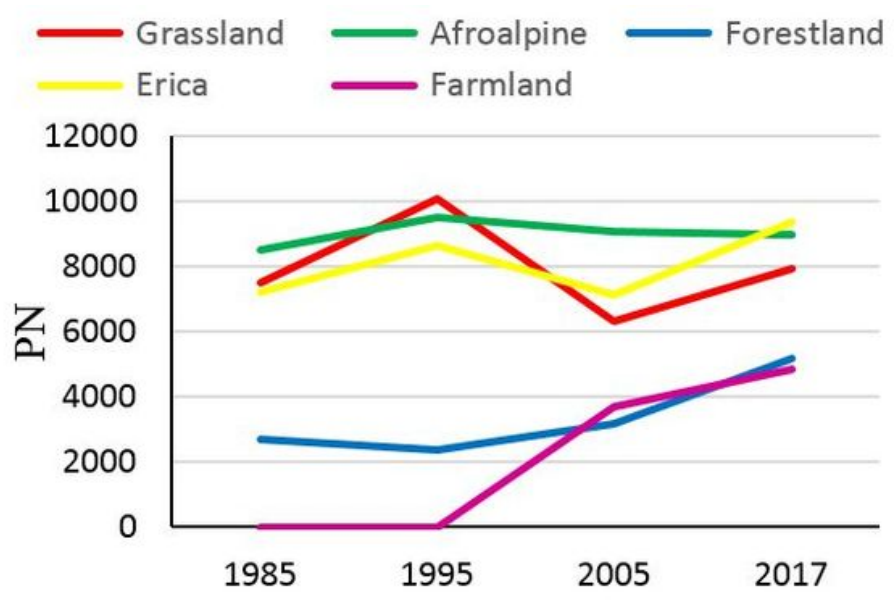

(a)

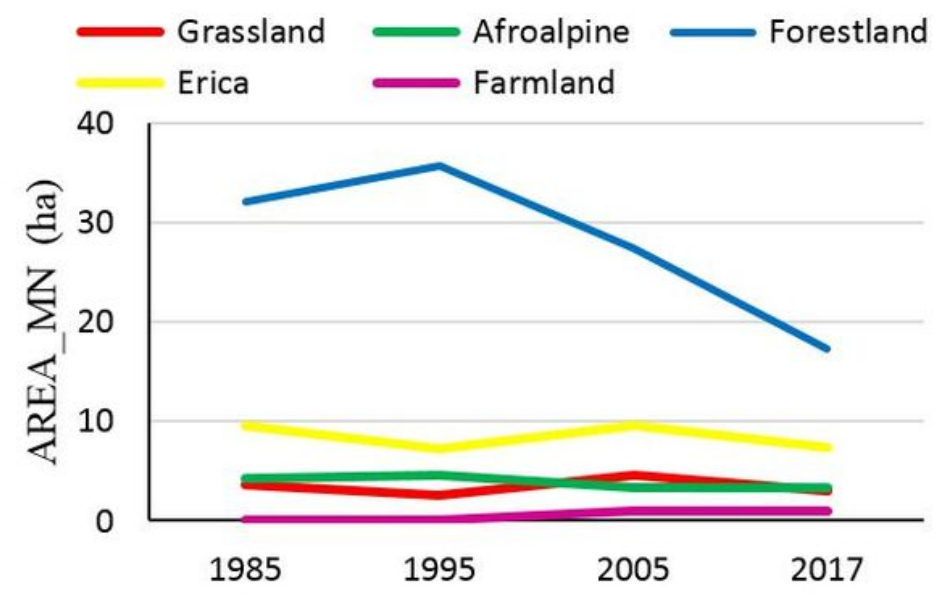

(b)

\section{Figure 5}

The change in patch number (PN) (a) and mean patch size (AREA_MN) (b) of each land cover classes from 1985 to 2017 


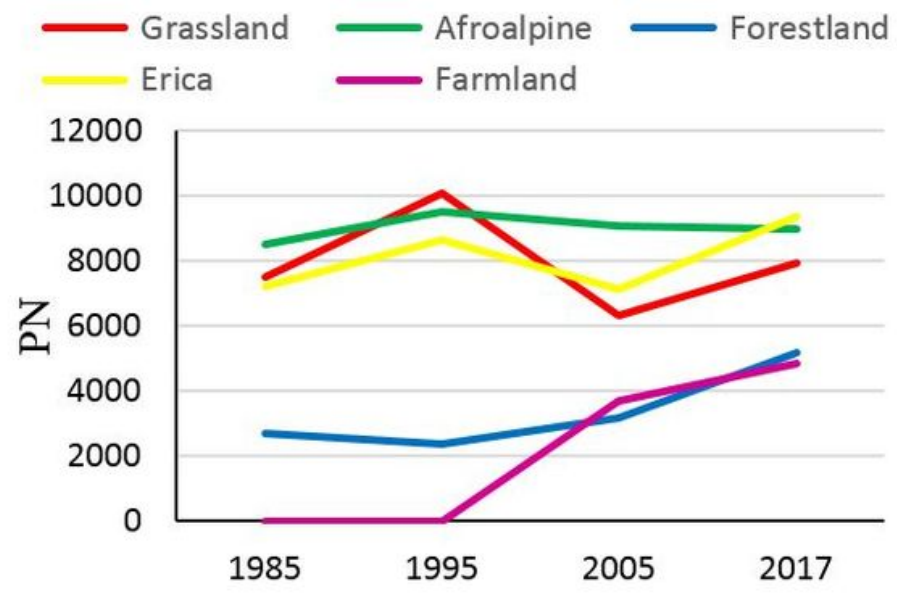

(a)

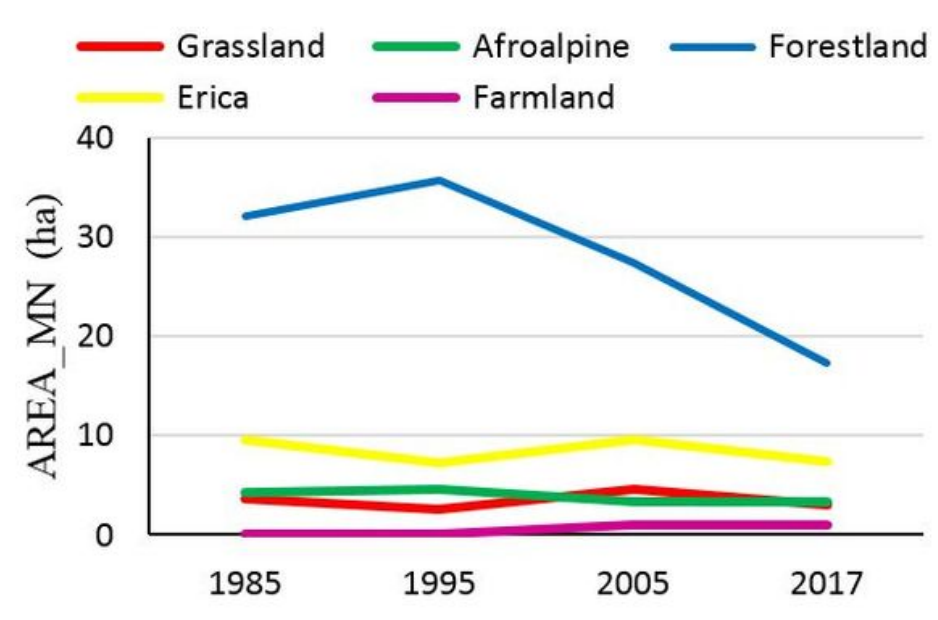

(b)

\section{Figure 5}

The change in patch number (PN) (a) and mean patch size (AREA_MN) (b) of each land cover classes from 1985 to 2017

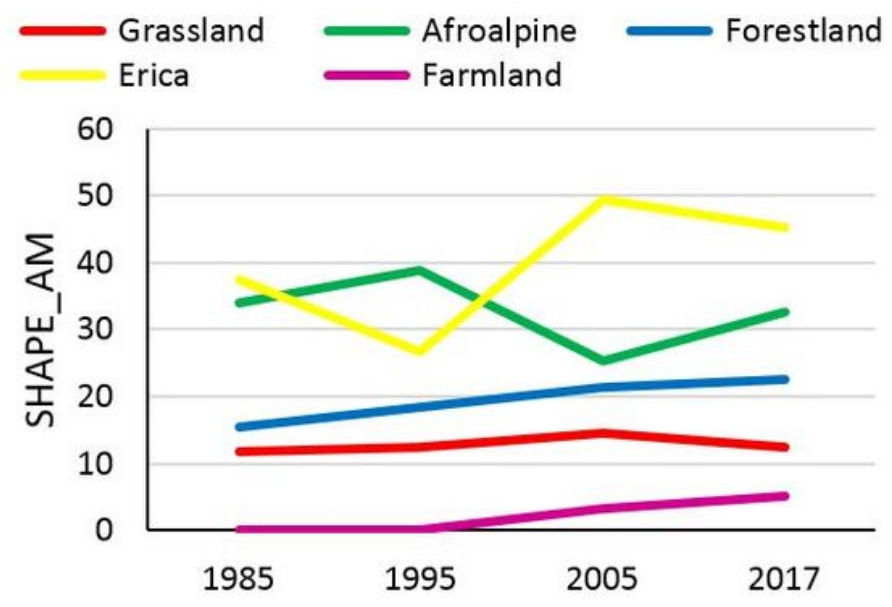

(a)

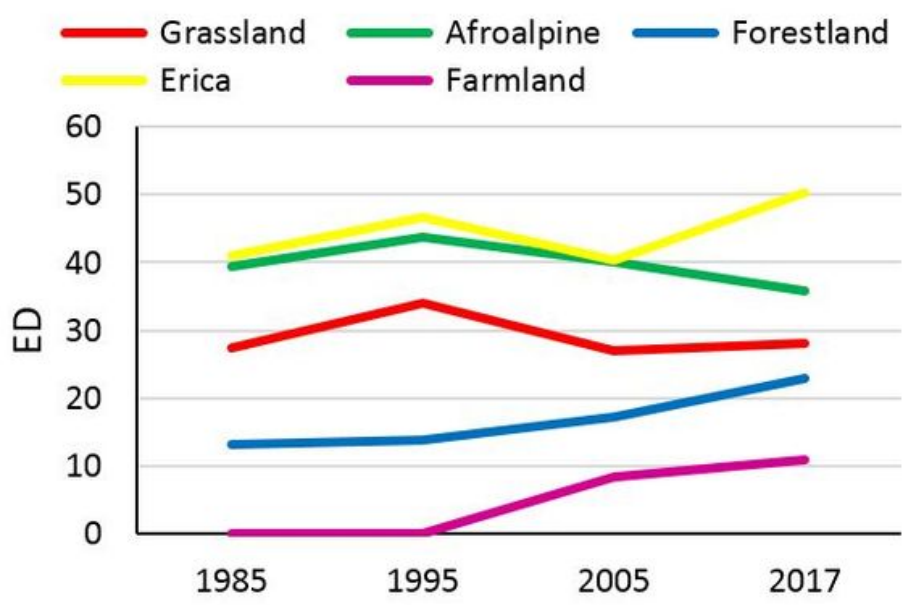

(b)

\section{Figure 6}

The change in area-weighted mean shape index (SHAPE_AM) (a) and edge density (ED) (b) of each land cover classes from 1985 to 2017 


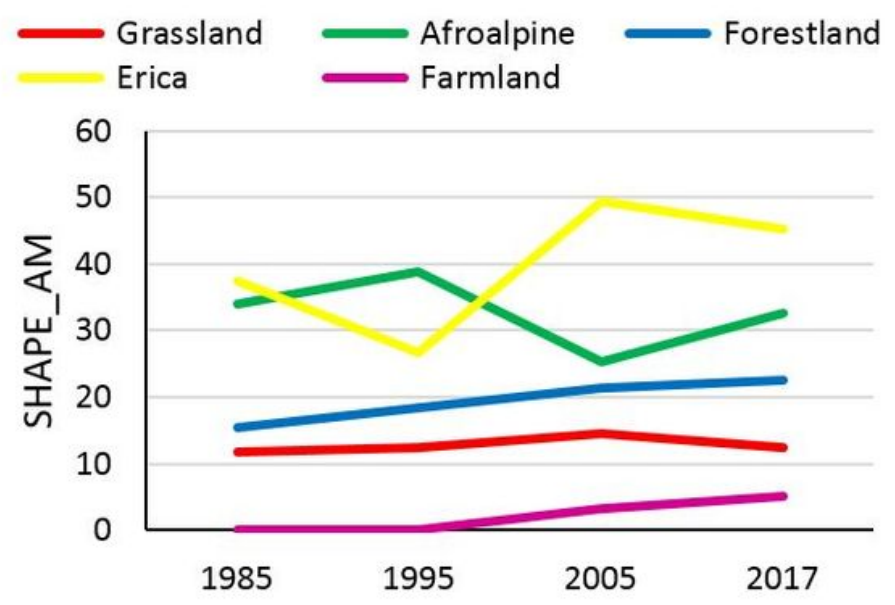

(a)

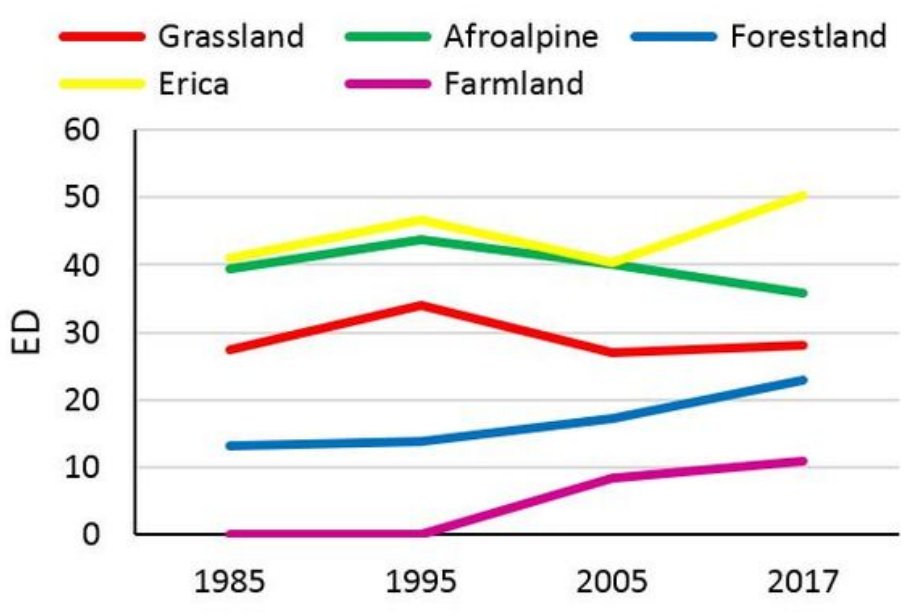

(b)

Figure 6

The change in area-weighted mean shape index (SHAPE_AM) (a) and edge density (ED) (b) of each land cover classes from 1985 to 2017

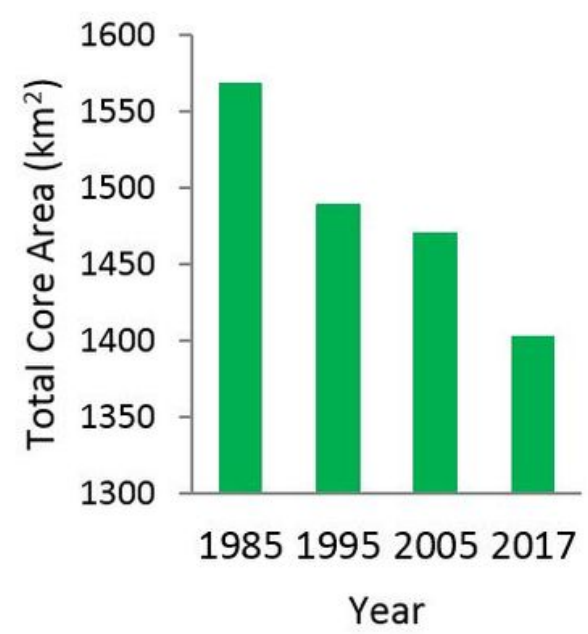

(a)

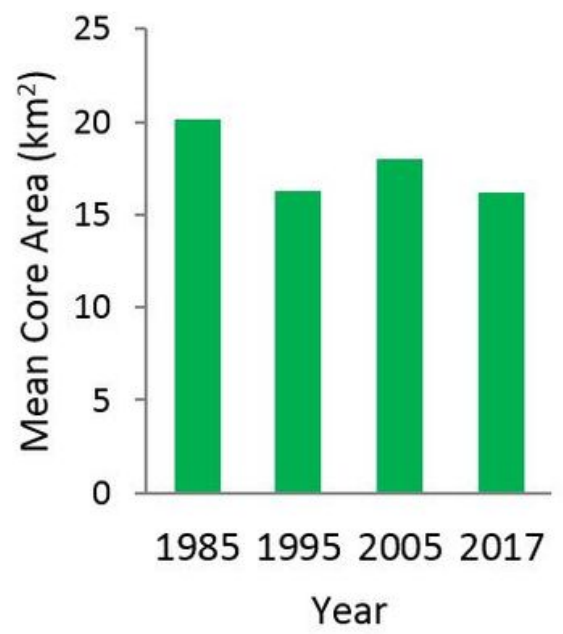

(b)

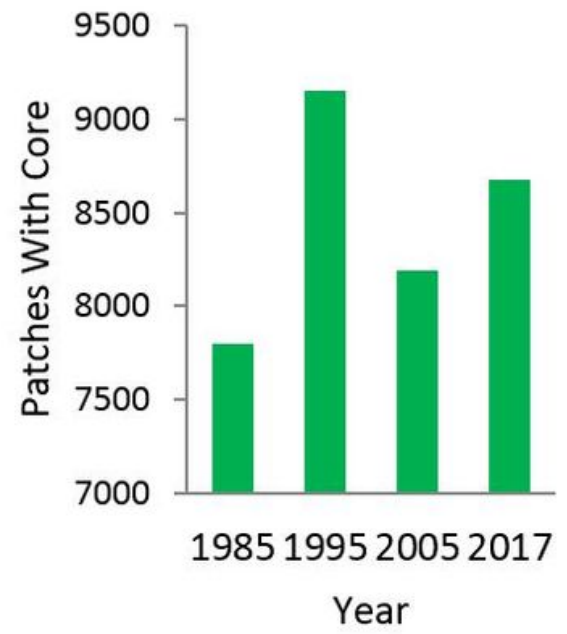

(c)

\section{Figure 7}

Change in total core area (TCA) (a), mean core area (COA) per patch (b), and number of patches containing core area (COA) (c) in the landscape level from 1985 to 2017 


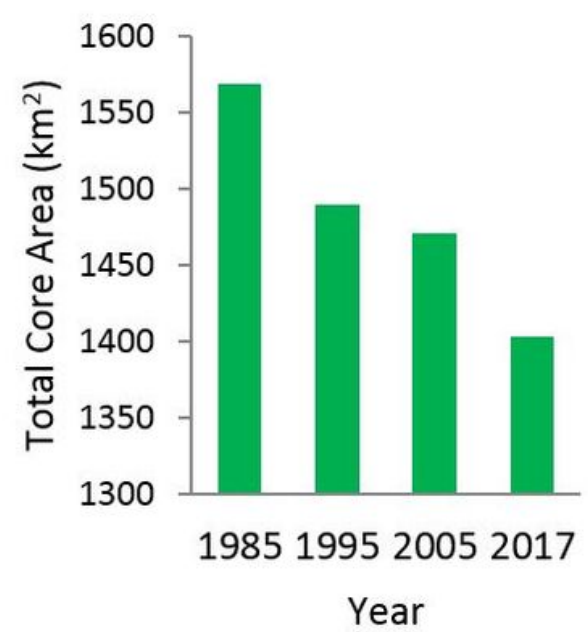

(a)

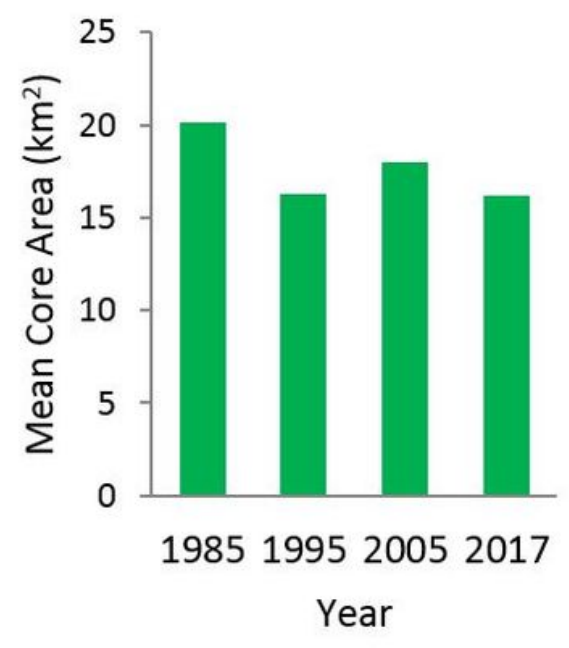

(b)

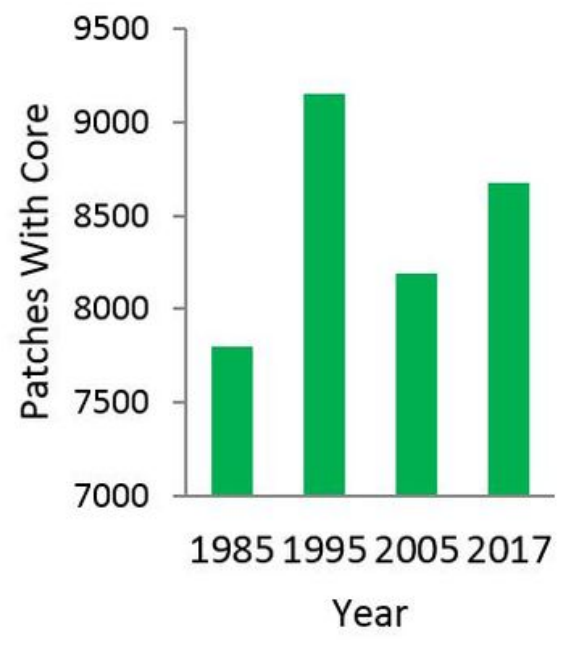

(c)

\section{Figure 7}

Change in total core area (TCA) (a), mean core area (COA) per patch (b), and number of patches containing core area (COA) (c) in the landscape level from 1985 to 2017

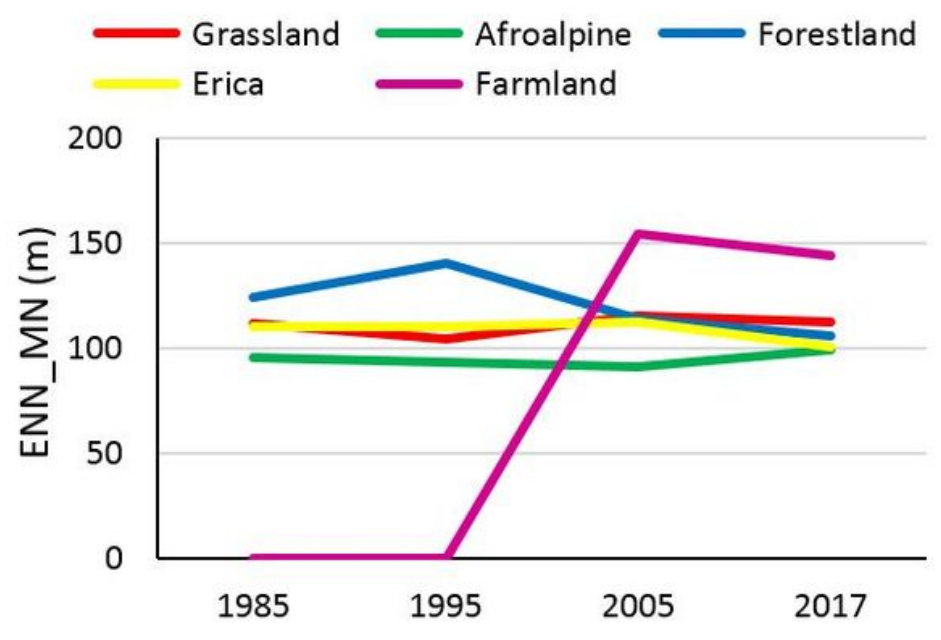

(a)

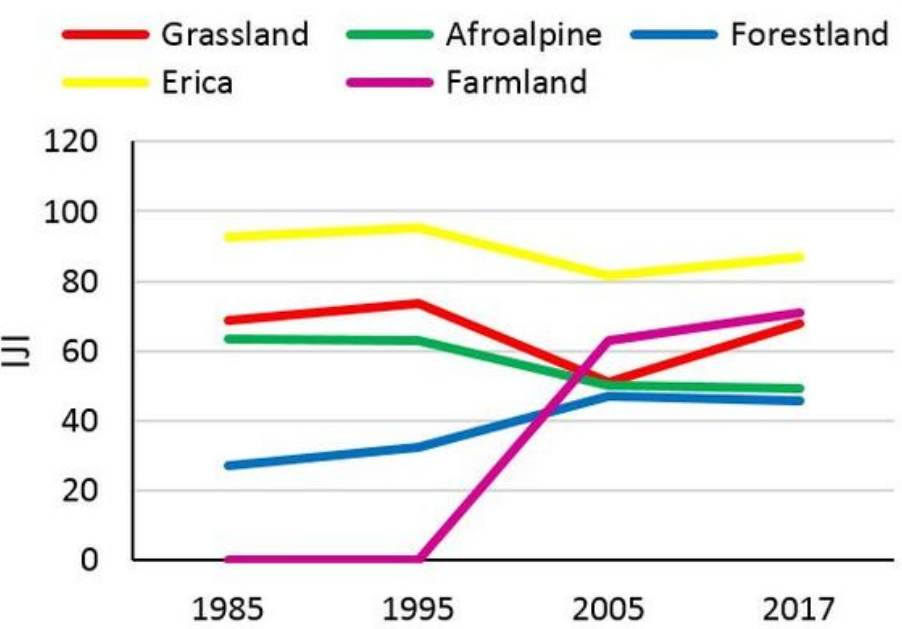

(b)

\section{Figure 8}

Change in Mean Euclidean nearest neighbor distance (ENN_MN) (a) and interspersion and juxtaposition index (IJI) (b) of each land cover classes from 1985 to 2017 


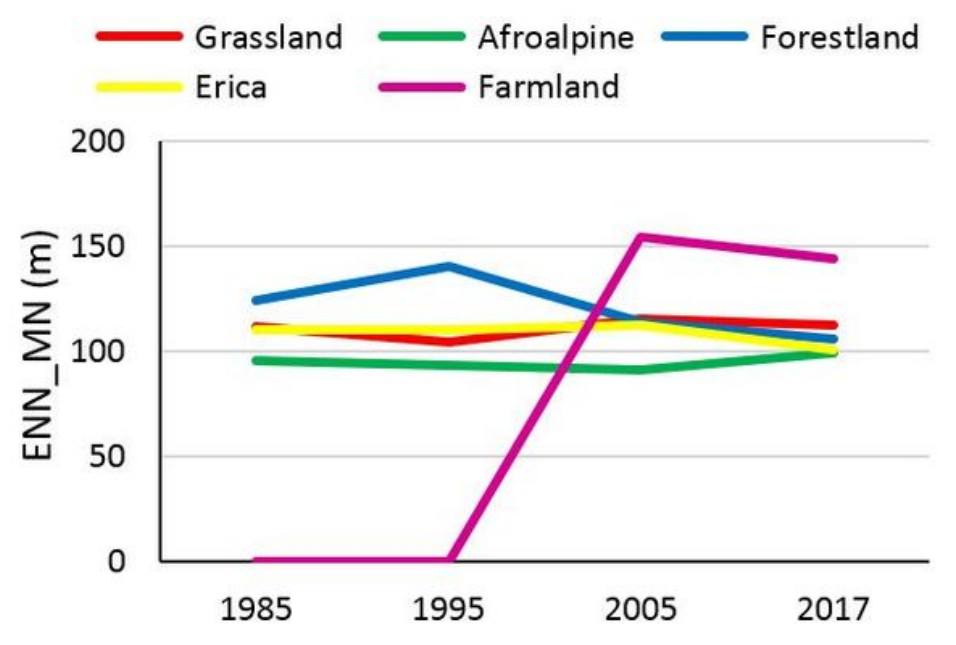

(a)

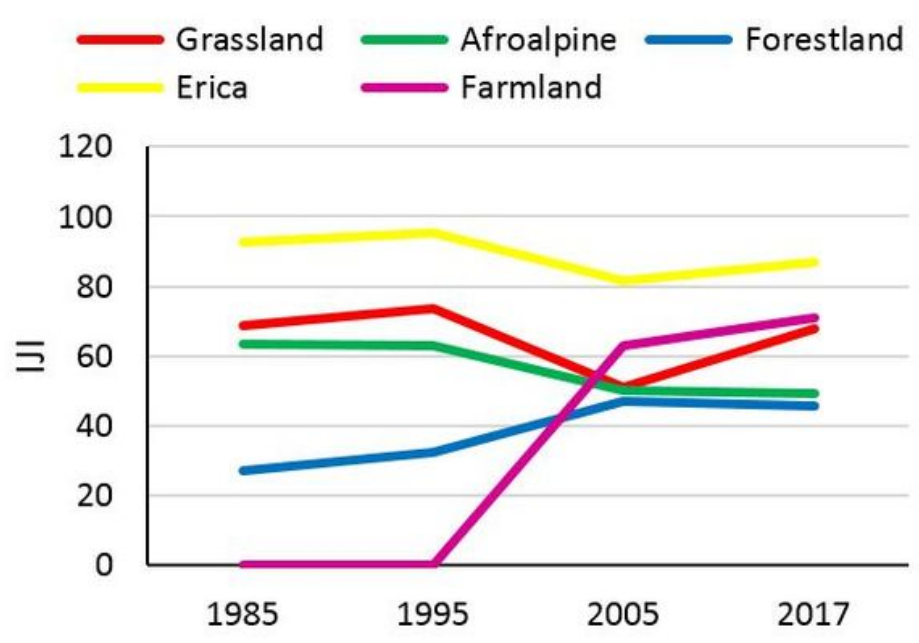

(b)

\section{Figure 8}

Change in Mean Euclidean nearest neighbor distance (ENN_MN) (a) and interspersion and juxtaposition index (IJI) (b) of each land cover classes from 1985 to 2017

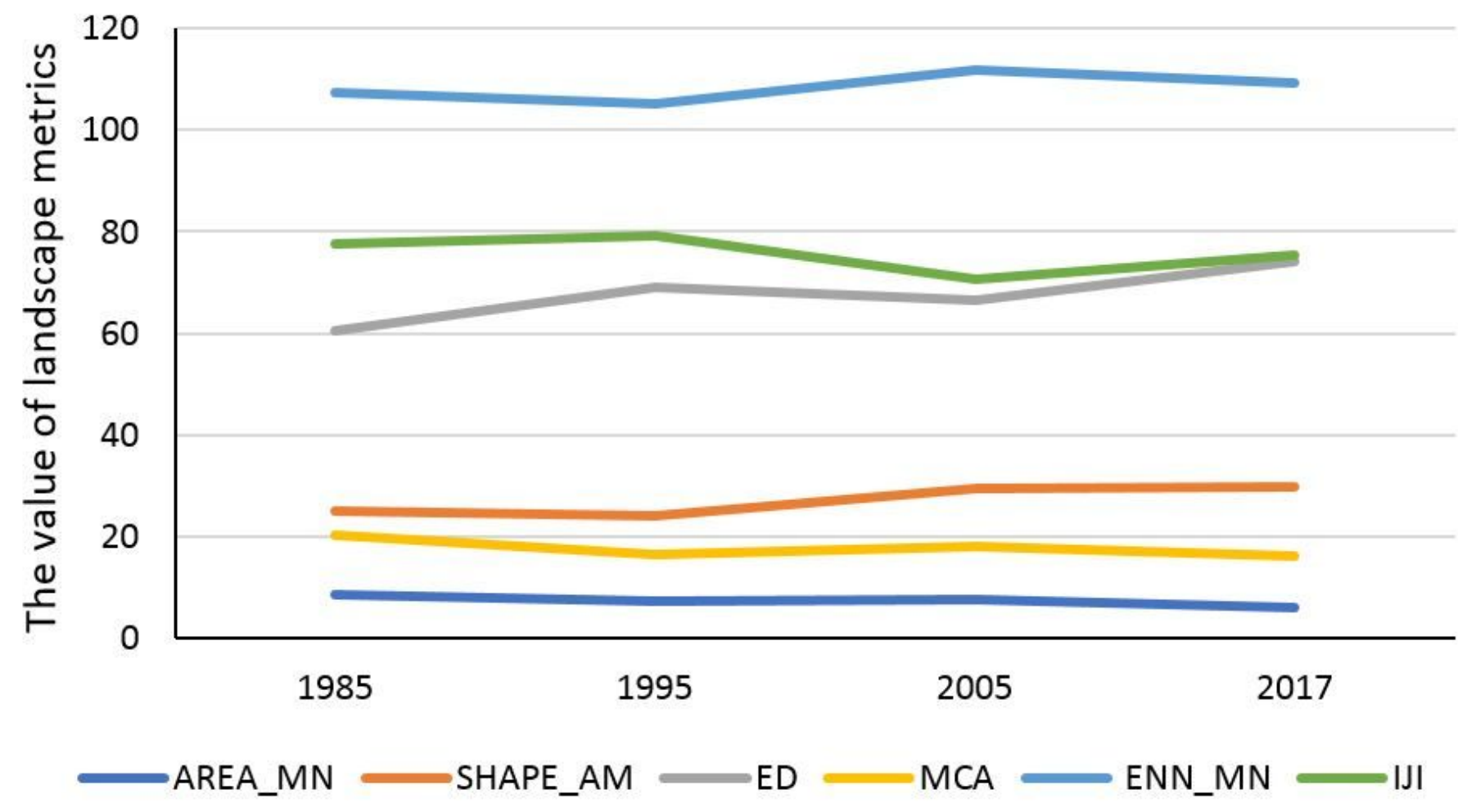

Figure 9

Landscape level changes of selected landscape metrics in the BMNP 


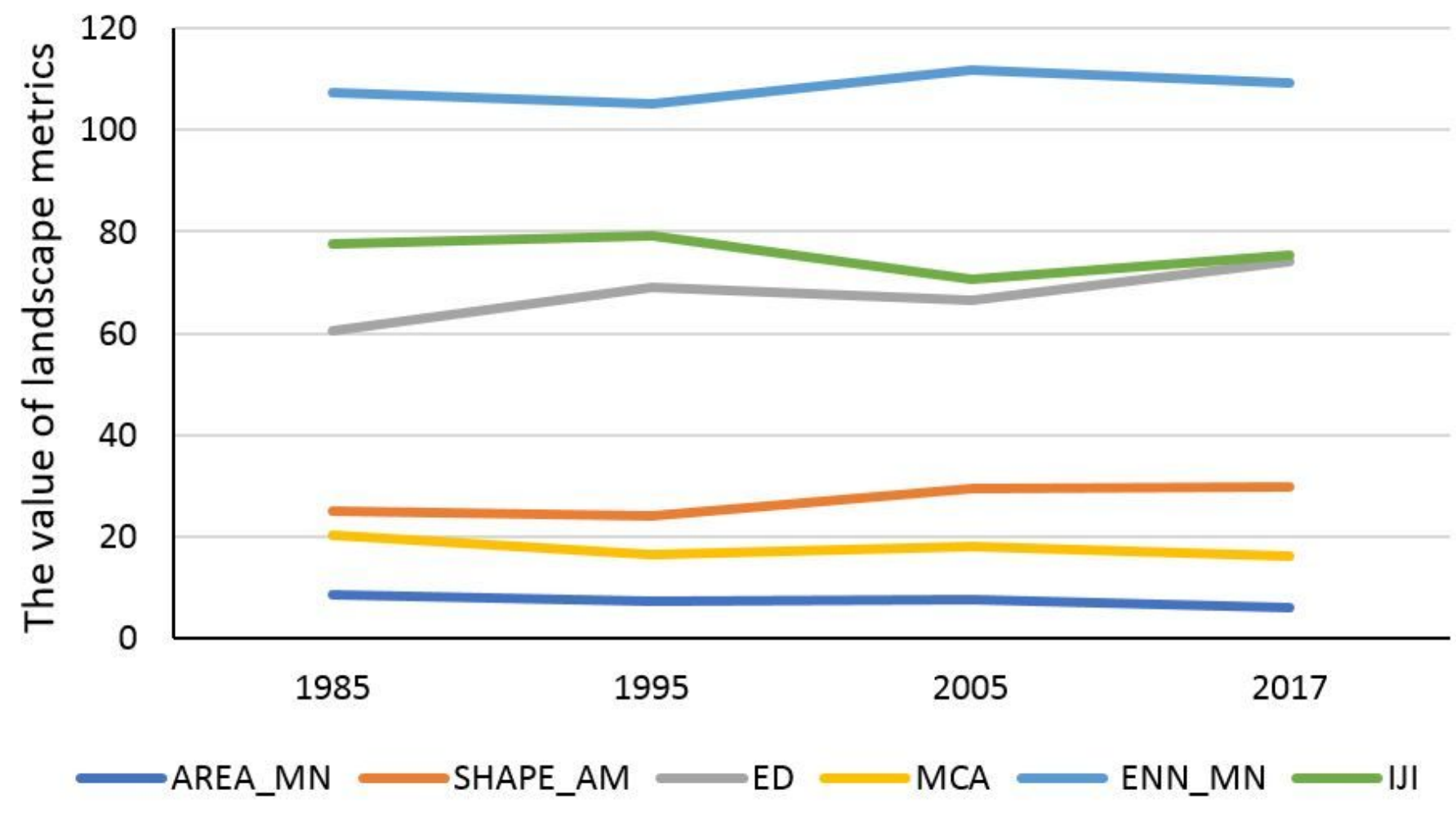

Figure 9

Landscape level changes of selected landscape metrics in the BMNP 